\title{
Moving towards Universal Coverage of Direct-Acting Antiviral Therapies for Hepatitis C Infection in Canada: An Environmental Scan of Canadian Provinces and International Jurisdictions
}

\author{
Samantha Myers ${ }^{\mathrm{a}}$, Gurleen Khosa ${ }^{\mathrm{a}}$, I fan Kuo ${ }^{\mathrm{a}}$, Donica Janzen ${ }^{\mathrm{a}}$, Silvia Alessi-Severini ${ }^{\mathrm{a}, \mathrm{b} *}$ \\ ${ }^{a}$ College of Pharmacy, Rady Faculty of Health Sciences, ${ }^{b}$ Manitoba Centre for Health Policy, Rady Faculty of Health \\ Sciences, University of Manitoba, Winnipeg, Manitoba, CANADA
}

Received, October 18, 2018; Accepted, November 4, 2018; Published, November 4, 2018.

\begin{abstract}
Background: Direct-acting antivirals (DAAs) have become the standard treatment for patients with chronic hepatitis $\mathrm{C}$ infections because of their high cure rates and favourable side effect profiles; however, access to this new class of agents has been limited because of its high cost. Public payers across Canada have implemented strict criteria for drug coverage in order to contain expenditures. Efforts have been made to improve access to medication for this high-burden condition. Recent coverage criteria across national and international jurisdictions have been compared.-Methods: Coverage criteria for several DAAs were reviewed by accessing Canadian provincial drug formularies. International coverage (e.g., Europe, Australia, United States, Egypt, India) was reviewed by searching available literature. Results: Coverage criteria vary across Canada. By April 2018, most Canadian jurisdictions had removed the stage 2 liver fibrosis requirement for patients to be eligible for coverage. Internationally, patients' access to DAAs differs significantly. Many jurisdictions restrict DAA prescribing authority to specialists and request documentation of chronic hepatitis $\mathrm{C}$. In the US, considerable gaps of coverage are identifiable and patients might face significant financial burden to receive treatment. Conclusion: DAAs appear to be generally accessible through public drug plans in Canada compared to other countries.
\end{abstract}

\section{INTRODUCTION}

With the emergence of oral direct-acting antivirals (DAAs) such as Harvoni ${ }^{\circledR}$ (ledipasvir/sofosbuvir), Sovaldi ${ }^{\circledR} \quad$ (sofosbuvir), and Epclusa ${ }^{\circledR}$ (sofosbuvir/velpatasvir), chronic hepatitis $\mathrm{C}$ (CHC) have gone from a once unsettling diagnosis to a curable disease. Approximately 71 million people globally are currently affected by $\mathrm{CHC} .{ }^{1}$ Hepatitis $\mathrm{C}$ virus $(\mathrm{HCV})$ is a bloodborne virus which can cause acute and chronic disease; highest-risk factors for infection include intravenous drug use, needlestick injuries, blood transfusions received before 1992, and receiving unsterile tattoos or body piercings. ${ }^{2}$ Acute HCV infection is often asymptomatic and rarely associated with life-threatening disease. While between 15 and $45 \%$ of infected persons spontaneously clear the virus within 6 months of infection without any treatment, the remaining 60 $80 \%$ of persons develop CHC, which, if untreated, develops in $15-30 \%$ of the cases into cirrhosis of the liver within 20 years ${ }^{1}$.

Treatment for $\mathrm{CHC}$ may vary according to virus genotype. In Canada, genotype 1 makes up about $65 \%$ of the patients infected with $\mathrm{HCV}$ (genotype 1a accounts for $56 \%$ and genotype $1 \mathrm{~b}$ for $33 \%$, with approximately $10 \%$ unspecified or mixed genotype ${ }^{3}$ ), genotype 2 makes up approximately $14 \%$ of $\mathrm{HCV}$ cases, while genotype 3 makes up roughly $20 \%{ }^{3}$ Genotypes 4, 5, 6, are quite rare, only accounting for $<1 \%$ of the infections in Canada. ${ }^{3}$

DAAs either work to inhibit the NS5A protein, NS3/4A protease, or NS5B RNA polymerase. ${ }^{4}$ All of these mechanisms of action ultimately result in inhibiting processes that are necessary for viral replication. ${ }^{4}$ Not only do these therapies help control the spread of the virus, they also reduce the incidence of CHC complications such as liver cirrhosis and hepatocellular carcinoma. $^{3}$ Before DAAs, the standard treatment for $\mathrm{CHC}$ was interferon (IFN) therapy. This consisted of low cure rates $(<10 \%)^{5}$ and severe side effects including fatigue, headache, nausea, dizziness, depression. ${ }^{6}$ Interferon therapy was then combined with ribavirin which increased cure rates to $34-42 \% .^{5}$

Corresponding Author: Dr. Silvia Alessi-Severini, College of Pharmacy, Rady Faculty of Health Sciences University of Manitoba, 750 McDermot Avenue, Winnipeg, Manitoba, Canada, Email: Silvia.Alessi-Severini@umanitoba.ca 
The substitution of IFN with PEGylated IFN resulted in sustained virologic response (SVR) rates ranging from $45-80 \% .^{5}$ The first DAAs, Victrelis ${ }^{\mathrm{TM}}$ (boceprevir) and Incivek $^{\mathrm{TM}}$ (telaprevir), were released in 2011, and showed cure rates of $70-80 \%{ }^{5}$ In 2014, the newer class of DAAs were released, all producing SVRs of $>90 \%{ }^{7,8}$

Compared to earlier interferon-containing regimens, not only do DAAs have increased SVR rates, they also have fewer side effects, making them much more tolerable courses of treatment. The only issue with these innovative drugs is the high price tag attached to them. As a result, both private and public insurers initially had to establish eligibility requirements that prioritized patients with liver damage, and those who had failed to respond to less costly treatments. Currently, criteria for coverage are changing globally, improving patients' access to DAAs. However, changes are occurring at different rates across the globe and access to treatment varies among countries. Previous treatments, liver fibrosis levels, degree of liver damage, or drug/alcohol use are still considered in coverage criteria. The purpose of this paper is to describe coverage criteria and cost differences across provinces and territories in Canada, as well as to explore how DAAs are covered in international jurisdictions.

\section{METHODS}

A systematic search of existing literature and Canadian provincial drug formularies was conducted between May and August 2018 to determine coverage criteria and prices of DAAs in various jurisdictions. Medications available on the Canadian market included Daklinza ${ }^{\circledR}$ (daclatasvir), Epclusa ${ }^{\circledR}$ (sofosbuvir/velpatasvir), Sunvepra ${ }^{\mathrm{TM}}$ (asunaprevir), Galexos ${ }^{\circledR} \quad$ (simeprevir), Harvoni ${ }^{\circledR}$ (ledipasvir/sofosbuvir), Sovaldi ${ }^{\circledR}$ (sofosbuvir), Holkira ${ }^{\circledR}$ Pak(dasabuvir, ombitasvir, paritaprevir, and ritonavir), Zepatier ${ }^{\circledR}$ (elbasvir/grazoprevir), Maviret $^{\mathrm{TM}}$ (glecaprevir/pibrentasvir), Technivie ${ }^{\mathrm{TM}}$ (ombitasvir, paritaprevir, and ritonavir), and Vosevi $^{\mathrm{TM}} \quad$ (sofosbuvir/velpatasvir/voxilaprevir). Information not available online was obtained from government agencies through phone conversations. Drugs not available in Canada, but available in other jurisdictions were also considered. A scan of current national and international media coverage on access to treatment, recommendations, and pricing regarding hepatitis $\mathrm{C}$ treatment was also performed and discussed. The recommendations of the Canadian Drug Expert Committee (CDEC) (the national committee providing recommendations to provincial/territorial/federal drug programs in Canada) for reimbursement of each DAA were also analyzed.

\section{RESULTS}

\section{International comparison}

An economic analysis looking at new medications for hepatitis C published by Iyengar ${ }^{9}$ in 2016 compared the costs for 12-week courses of Sovaldi ${ }^{\circledR}$ (sofosbuvir) or Harvoni ${ }^{\circledR}$ (ledipasvir/sofosbuvir) in 30 different countries (including Japan, Poland, Greece, Turkey, United States, Brazil, Egypt). The study showed that prices for these medications varied significantly among countries and estimated that total cost of treating all patients with $\mathrm{CHC}$ would be at least a tenth of the current annual drug spending in all of the 30 countries. ${ }^{9}$ In certain countries where the prices of medications and disease prevalence is high, the total cost of treating all patients would be more than the current annual drug spending of all other medications. ${ }^{9}$ Another observation was that if a patient had to pay out of pocket for the medication, the total cost of a 12-week course of sofosbuvir alone was equivalent to one year or more of earnings from an average salary in 12 of the 30 countries included in the study. ${ }^{9}$ The overall conclusion of this article was that the new medications for hepatitis $\mathrm{C}$ were "globally unaffordable". 9 As a consequence of the high prices, payers in high-income countries have been restricting coverage (e.g., United States), negotiating public deals, private discounts, and rebates with the manufacturer (e.g., France and Germany), or delaying reimbursement until a reasonable price has been negotiated (e.g., Australia). ${ }^{9} \quad$ In low- and low-middle-income countries, where pricing negotiations have been undertaken or generic formulations of DAAs have been made available, access to treatment has vastly improved. The World Health Organization (WHO) published a progress report on Access to Hepatitis C Treatment focusing on low- and middle-income countries in March 2018. This publication described the steps that needed to be taken towards developing universal coverage for hepatitis $\mathrm{C}$ treatment, which included access to affordable treatment as the primary step as well as the need for strong government involvement in order to ensure that 
prevention measures and adequate screening protocols were implemented globally. ${ }^{10}$ In uppermiddle- and high-income countries, prices of DAAs remain high with access to generic formulations very limited. While the price of DAAs is still extreme in high-income countries, diagnostic services are more easily accessible compared to low-income countries.

Many factors play a role in determining the cost of newly approved medications. They include investment in research and development, production costs, efficacy, safety, ease of administration, duration of treatment, features of treatment comparators, innovation, international benchmarking, market size and market value. ${ }^{5}$ It has been shown that the cost of treating hepatitis $\mathrm{C}$ is incremental, but so is the cost of treating the complications that will arise later on if left untreated. In fact, while prevalence of hepatitis $\mathrm{C}$ is declining, probably due to better education on prevention and to the availability of DAAs, the $\mathrm{CHC}$ population is aging and the rate of complications is increasing. It has been estimated that, in Canada, direct costs associated with $\mathrm{CHC}$ (not including cost of antivirals) would increase from an estimated $\$ 161$ million in 2013 to more than $\$ 258$ million at the peak in 2032. ${ }^{11}$

In June 2015, prices for sofosbuvir, daclatasvir, simeprevir, ledipasvir/sofosbuvir and ombitasvir/paritaprevir/ritonavir were surveyed in various jurisdictions in a study published in November 2015 entitled "Disparity in market prices for hepatitis $\mathrm{C}$ virus direct-acting drugs". ${ }^{12}$ Thirtyeight countries were included: 14 were high-income countries, 9 were upper-middle-income countries, 11 were lower-middle income countries, and 4 were low-income countries. Classification was based on their GNI per capita (in U.S. dollars, converted from local currency). ${ }^{12}$ The price per bottle of sofosbuvir was $\$ 300$ in India and Pakistan and $\$ 20,590$ in Switzerland. The cost per bottle of daclatasvir was \$175 in Egypt and \$14,899 in Germany. Simeprevir ranged from \$241per bottle in Egypt to $\$ 14,865$ in Australia. ${ }^{12}$ Ledipasvir/sofosbuvir costs were $\$ 400$ per bottle in Egypt and Mongolia but $\$ 24,890$ per bottle in Germany. ${ }^{12}$ Finally, ombitasvir/paritaprevir/ritonavir costs were $\$ 400$ per bottle in Egypt but $\$ 20,215$ per bottle in Switzerland. ${ }^{12}$ This study concluded that prices of DAAs in low-income and middle-income countries were substantially lower compared to high-income countries, with few exceptions. This survey stressed the concept that these medications were unaffordable for patients who have to pay out of pocket in highincome countries or if large populations require treatment paid by a government payer. ${ }^{12}$

\section{Australia}

Australia has established a cost-appropriate plan for the treatment of CHC. The Pharmaceutical Benefits Scheme (PBS) is a program that negotiates prices with manufacturers on behalf of the residents of Australia. On March 1, 2016, all HCV patients were able to access available DAAs through the PBS. ${ }^{13}$ The Australian government made a deal with PBS to pay 1 billion Australian dollars over 5 years to subsidise DAAs. ${ }^{13}$ A year after this change was made, a study entitled "Implementation of hepatitis $\mathrm{C}$ cure in Australia: one year on" was published in the Journal of Virus Eradication (Richmond \&Wallace, 2018) ${ }^{14}$. The conclusion was that the goal to eliminate $\mathrm{HCV}$ in Australia had become a realistic possibility. ${ }^{14}$ By making DAAs more accessible, the percentage of Australians being tested and diagnosed had also increased. ${ }^{14}$ As of 2018, approximately 227,306 people were living with HCV in Australia. ${ }^{13}$ Because of the increased access to DAAs through the PBS, an estimated 43,360 Australians (approximately $19 \%$ of the CHC population) were started on DAA therapy between March 2016 and June 2017. ${ }^{14}$

For Epclusa ${ }^{\circledR}$, which is effective against all genotypes of $\mathrm{HCV}$, patients were only required to pay $\$ 6.30$ if they were "concessional" patients and $\$ 38.80$ in all other cases. ${ }^{11} \mathrm{~A}$ concessional patient is one who holds any of the following cards: Pensioner Concession Card, Australian Seniors Health Card, Health Care Card, or a Department of Veterans' Affairs (DVA) Gold, Orange, or White Card. ${ }^{15}$ DAAs available to patients through the PBS as of August 1, 2018 included the following: Daklinza ${ }^{\circledR}$, Epclusa ${ }^{\circledR}$, Harvoni ${ }^{\circledR}$, Maviret ${ }^{\circledR}$, Sovaldi ${ }^{\circledR}$, ViekiraPak ${ }^{\circledR}$, Viekira-Pak ${ }^{\circledR}$ with RBV ${ }^{\circledR}$, and Zepatier ${ }^{\circledR} .{ }^{16}$

Australia has a program of unrestricted access to DAAs, the only criterion requires for the patient to be an adult diagnosed with CHC. This is in contrast to most countries that have programs of restricted access that would only allow those with advanced disease or those previously treated with other therapy to be eligible for coverage. In other countries, patients might be denied access if they are abusing drugs or alcohol. "The key to this universal access was the Australian government's capacity to negotiate much lower drug prices than in other high- 
income countries, following strong advocacy from the hepatitis $\mathrm{C}$ sector. For instance, Australia paid an estimated ten-fold lower price per patient treated in 2016 than did Germany." 17

France and Scotland have a process similar to the Australian process that provides payment for all CHC patients with minimal co-payments. ${ }^{18}$

\section{Europe}

As of March 2018, approximately 36\% of Europeans with CHC infection had been diagnosed, and approximately $5 \%$ had received treatment. ${ }^{19}$ The WHO has set a goal to eliminate hepatitis B and C as a public health threat by 2030 . In order to reach that target, $90 \%$ of people living with $\mathrm{CHC}$ will have to be diagnosed and $80 \%$ of those diagnosed will have to be treated with DAAs. ${ }^{10}$ High-risk populations need to be tested in order to increase diagnoses and restrictions to DAA treatment need to be further removed worldwide in order to increase access to treatment to meet these targets.

Previous restrictions in Europe for DAA prescribing included prioritizing therapy for those who had liver damage and limiting prescribing to specialists (e.g. gastroenterologist, hepatologist, or infectious disease specialist) or physicians with experience treating hepatitis C. ${ }^{19}$ Certain restrictions for DAA coverage are slowly being removed across European jurisdictions, increasing access to DAAs. ${ }^{19}$

In February 2018, a study entitled "Restrictions for reimbursement of interferon-free direct acting antiviral drugs for $\mathrm{CHC}$ infection in Europe" (Marshall, 2018) was published; this study compared reimbursement criteria of DAAs in 35 European countries (which included those in the European Union, European Economic Area and Switzerland) between November 18, 2016 and August 1, 2017. ${ }^{20}$ They concluded that $46 \%$ of countries in the study still had fibrosis requirements in place in order for patients to receive treatment and $94 \%$ of countries restricted prescribing to a specialist ${ }^{20} 83 \%$ of these European countries had no restrictions to limit treatment to those who were abstinent from drugs or alcohol. ${ }^{20}$ Only $3 \%$ of countries had additional restrictions for those that were co-infected with HIV. ${ }^{20}$ This study concluded that these findings had the potential of meeting WHO targets of eradicating $\mathrm{HCV}$ as a public health threat by $2030 .{ }^{20}$ Since this study was completed, more European countries including Finland, Norway, Liechtenstein, Scotland,
Sweden and Switzerland have removed the fibrosis requirement for DAA treatment. ${ }^{19}$

\section{Mongolia}

Mongolia has the highest rate of liver cancer in the world due to the high prevalence of $\mathrm{CHC}$. Approximately $6.8 \%$ of the Mongolian population is chronically infected with HCV. ${ }^{18}$ In efforts to improve treatment access, the Mongolian government has established one of the lowest prices for sofosbuvir/ledipasvir across the globe. $^{18}$ Harvoni ${ }^{\circledR}$ (sofosbuvir/ledipasvir) and 4 generics are available in Mongolia for either US\$300 (brand) or US\$150 (generics). ${ }^{21}$

\section{United States}

There are approximately 3.2 million people living with $\mathrm{CHC}$ in the United States. ${ }^{22}$ With the new DAAs becoming available in 2014, the national US spending on hepatitis $\mathrm{C}$ drugs increased considerably. Spending on hepatitis C drugs in Medicare Part D jumped from $\$ 283$ million in 2013 to $\$ 4.5$ billion in $2014 .^{23}$ In 2016, an article entitled "Coverage for hepatitis C drugs in Medicare Part D" was published in NCBI which analyzed the spending of insurance plans on HCV drugs and estimated the total patients' out-of-pocket spending. ${ }^{23}$ They concluded that "All Part D plans covered at least 1 recently introduced HCV drug, as of July 2015. Nearly all plans charged relatively high co-payments and required prior authorization for newer HCV drugs. For enrollees with no subsidy, the mean out-of-pocket spending ranged from $\$ 6,297$ to $\$ 10,889$. For enrollees with a low-income subsidy, out-of-pocket spending varied between $\$ 10.80$ and $\$ 1,191 " .{ }^{23}$ The authors also found that at the time of the study, all Part D plans covered simeprevir and sofosbuvir and $98 \%$ of plans covered ledipasvir/sofosbuvir. ${ }^{23}$ Currently, $\mathrm{CHC}$ patients with or without subsidy still face sizable financial burdens in the United States. ${ }^{23}$

The U.S. has outlined similar restrictions to treatment as Europe. In 2015, an environmental scan was published that analyzed the reimbursement restrictions for sofosbuvir in the United States between June 23, 2014 and December 7, 2014. ${ }^{24}$ Criteria for coverage in all 50 states and the District of Columbia were assessed. ${ }^{24}$ Out of the 42 states with known Medicaid reimbursement criteria for sofosbuvir, $74 \%$ of states limited treatment to those with fibrosis (METAVIR score F3) or cirrhosis (METAVIR score F4), $88 \%$ of states had restrictions 
based on drug/alcohol use, and $67 \%$ of states restricted prescribing of DAAs to specialists. ${ }^{19,24}$

An updated review of coverage criteria was published in 2017 (Conolly, J.) which analyzed restrictions to DAA treatment in the U.S. between August 20, 2016 and September 10, 2016. ${ }^{25}$ This study also analyzed all 50 states as well as the District of Columbia ${ }^{25}$ and concluded that 15 states loosened fibrosis requirements compared to the results in $2014 .{ }^{19,25}$ As of 2016, only 22/51 (43\%) states restricted coverage to patients with a METAVIR score of F3 or F4, ${ }^{25}$ compared to $74 \%$ in 2014 as stated above, ${ }^{19,24} 34 / 51$ (67\%) restricted prescribing to gastroenterologists, hepatologists, or infectious diseases specialists, as it was in 2014. Some states (including Minnesota, New Hampshire, Montana, New York, Rhode Island, and Washington State) granted certain physicians with special training right to prescribe DAAs. ${ }^{25}$ Twenty-nine (57\%) states allowed patients with decompensated cirrhosis to receive coverage, but 5/51 (10\%) of states excluded these patients from receiving coverage. ${ }^{25}$ South Dakota is the only state that required a biopsy; ${ }^{25} 20 / 51$ (39\%) of states required for all patients to be abstinent from drugs or alcohol in order to receive treatment. ${ }^{25}$

\section{India}

The Indian population accounts for approximately 12 million out of the 71 million of those infected globally. ${ }^{26}$ Sofosbuvir, ledipasvir and daclatasvir are now available as generic alternatives in India, which has greatly improved access to treatment. These three generic medications are available to patients at the reasonable price of approximately $\$ 250$ $\$ 300 /$ bottle. $^{27}$

In January 2016, the lowest price for a 28-day supply of a generic combination of sofosbuvir/ledipasvir by Indian licensees of the originator company for the local Indian market was US\$205; by April 2016, it had dropped to US\$169. ${ }^{28}$ The lowest price reported for a 28 -day supply of sofosbuvir in January 2016 from a local generic producer was US\$15 in Pakistan. ${ }^{28}$ Due to generic formulations, price reductions have been obtained, increasing the amount of people able to be treated.

\section{Egypt}

As of June 2017, Egypt was reported to be the country with the highest prevalence of hepatitis $\mathrm{C}$ in the world at approximately $10 \% .{ }^{29}$ Upon initial marketing of new DAAs in 2014, Gilead Sciences priced the drug to the U.S. market at $\$ 1,000 /$ pill making a 12-week course cost $\$ 84,000 .{ }^{30}$ Gilead Sciences marketed sofosbuvir combined with ledipasvir (Harvoni ${ }^{\circledR}$ ) with a 12-week treatment cost of $\$ 94,500 .{ }^{11}$ As of September 2016, after the Egyptian government negotiated prices with Gilead, Sovaldi ${ }^{\circledR}$ became available for $\$ 250 /$ bottle, and Epclusa ${ }^{\circledR}$ and Harvoni ${ }^{\circledR}$ for $\$ 300 /$ bottle. ${ }^{31}$

\section{Other countries}

According to the WHO, as of September 2016, daclatasvir has been made available for US\$120 in Morocco, US\$61 in India and down to US\$7 in Egypt. ${ }^{28}$ Other countries such as Indonesia, Afghanistan, Kenya, South Africa, and Morocco also enjoy lower prices for Sovaldi ${ }^{\circledR}$. With affordable drugs, many Egyptians have been able to receive treatment. In fact, between 2014 and 2017, 1.6 million Egyptians received treatment for $\mathrm{HCV} .{ }^{31}$

\section{Canada}

In Canada, CDEC of the Canadian Agency for Drugs and Technologies in Health (CADTH) Common Drug Review makes reimbursement recommendations to provincial/territorial drug plans (excluding Québec), as well as federal drug programs, after a drug becomes available on the Canadian market. Each jurisdiction, however, makes the final decision on the coverage implementation for each medication.

Unlike other countries, Canada has no national strategy for eliminating hepatitis $\mathrm{C}$ as a public health threat. ${ }^{32}$ The Canadian Hemophilia Society describes the five aspects that a national plan must have for population-specific strategies, national targets with well-defined indicators, increased access to treatment, continuum of $\mathrm{CHC}$ services and most importantly, adequate resources. ${ }^{32}$

\section{What's in the media for Canada}

The Canadian media is always highly interested in health care issues. Since the first oral DAAs, Victrelis $^{\mathrm{TM}}$ (boceprevir) and Incivek ${ }^{\mathrm{TM}}$ (telaprevir), were approved in 2011, there have been countless news articles regarding hepatitis $\mathrm{C}$ treatment, screening, and prices of medications. Incivek was later discontinued from the Canadian market on January $1,2015^{33}$ and Victrelis was discontinued on March 31, 2016. ${ }^{34}$ Reasons for discontinuation 
included the need for adjunctive treatment with ribavirin and pegylated interferon, increasing costs of therapy and side effects ${ }^{3,33,34}$, and the lower cure rates that they produced compared to the newer DAAs released in 2014 such as sofosbuvir. ${ }^{3}$ A Globe and Mail article published in February of 2017 details the negotiations that the pan-Canadian Pharmaceutical Alliance (pCPA) conducted with manufacturers on behalf of the public drug programs. Agreements have been reached with the makers of six hepatitis $\mathrm{C}$ medications. The three drug companies involved were Gilead Sciences Canada, Merck Canada, and Bristol-Myers Squibb Canada. The deal further reduced the price of Harvoni ${ }^{\circledR}$ and Sovaldi ${ }^{\circledR}$, which were involved in an earlier price reduction agreement, and has more recently reduced prices of Daklinza ${ }^{\circledR}$, Epclusa ${ }^{\circledR}$, Sunvepra ${ }^{\mathrm{TM}}$, and Zepatier ${ }^{\circledR} .{ }^{35}$

\section{Provincial comparison}

Criteria for coverage differ not only from country to country, but also across Canadian provinces and territories. Setting criteria for reimbursement presents an ethical issue. How can we choose to cover the cost of life-saving treatments for some and not others? Previously, most provincial jurisdictions only covered treatment for those with a certain fibrosis level or liver damage, but not for those with an otherwise healthy liver. Effective April 27, 2018 Alberta, Saskatchewan, Yukon, Manitoba, and the NIHB program (federal drug program covering First Nation populations) cover the cost of hepatitis C treatment without restriction. ${ }^{36}$ Before this was implemented, patients in these provinces needed to demonstrate a liver fibrosis stage 2 (even though there was no clinical support for this limitation) or had another health issue such as HIV, hepatitis B virus or diabetes in order to be eligible for coverage. ${ }^{36}$ Prince Edward Island, Ontario, British Columbia and Québec had previously lifted restrictions based on liver injury. ${ }^{36}$

CDEC recommendations for each DAA were relatively similar. Most recommendations restricted DAA prescribing privileges to a specialist (i.e., gastroenterologist, hepatologist, or infectious disease specialist) or a physician with experience treating hepatitis $\mathrm{C}$ and recommended a reduction in price. Details are reported in Appendix (Table 1-12)

Table 1 describes which Canadian provinces and territories cover DAAs. Exception drug status or special authorization applications are required for all DAAs in Canada.

Table 2 describes the unit price of DAAs in Canadian jurisdictions. The cost of DAAs are similar across the provinces and territories with the exception of Holkira ${ }^{\circledR}$ Pak. From searching provincial drug formularies, the unit price for Holkira ${ }^{\circledR}$ Pak in most provinces was found to be around $\$ 600$, but in Alberta and New Brunswick, the unit price is approximately $\$ 166$.

Table 3 summarizes the recommendations for reimbursement by CDEC for each DAA.

Tables 4-12 describe the exact criteria that must be met in order for each DAA to be covered in each province/territory, the approved duration of therapy, and if adjunctive treatment is required. Across the provincial jurisdictions, certain similarities exist regarding coverage criteria. Most require that the treatment is prescribed by a hepatologist, gastroenterologist, infectious disease specialist, or other prescriber experienced in treating hepatitis $\mathrm{C}$, patients must have laboratory confirmed hepatitis $\mathrm{C}$, and confirmed quantitative HCV RNA values within the last 6-12 months. The fibrosis requirement has been removed from all Canadian jurisdictions with the exception of Nova Scotia, New Brunswick, and Newfoundland \& Labrador. $^{36}$ Alberta, British Columbia, Saskatchewan, Nunavut, and Northwest Territories have the widest range of DAAs available. Sunvepra ${ }^{\mathrm{TM}}$ and Galexos ${ }^{\circledR}$ were included in this environmental scan even though they have been removed from the Canadian market, as some provinces still include them on their formulary. Both Maviret $^{\mathrm{TM}}$, approved in November 2015, and Technivie $^{\mathrm{TM}}$, approved in September 2017, are not yet covered by any Canadian jurisdiction. A recent study published in January 2018 showed that those treated with Maviret ${ }^{\mathrm{TM}}$ for 8 weeks are showing very similar SVRs as those treated for 12 weeks. ${ }^{37}$ Being able to reduce therapy from 12 weeks to 8 weeks while maintaining efficacy will not only reduce costs dramatically, but will also increase the amount of people able to be treated in resource-limited settings. ${ }^{37}$

\section{British Columbia}

B.C. is one of the provinces with a wider range of availability for DAAs. Holkira ${ }^{\circledR}$ Pak was previously 
covered by BC Pharmacare, but as of March 23, 2017, it is not covered for those starting a new therapy. As of March 13, 2018, the following DAAs are covered by BC Pharmacare: Harvoni ${ }^{\circledR}$, Zepatier ${ }^{\circledR}$, Epclusa ${ }^{\circledR}$, Sunvepra ${ }^{\mathrm{TM}}$, Vosevi ${ }^{\mathrm{TM}}$, Sovaldi ${ }^{\circledR}$, and Daklinza ${ }^{\circledR} .{ }^{38}$

\section{Alberta, Saskatchewan, \& Manitoba}

These 3 provinces cover most DAAs, excluding Galexos ${ }^{\circledR}$ and Sunvepra ${ }^{\mathrm{TM}}$. Manitoba also excludes Vosevi $^{\mathrm{TM}}$ and Holkira ${ }^{\circledR}$ Pak.

\section{Ontario}

Ontario is one of the most progressive provinces in Canada regarding access to hepatitis $\mathrm{C}$ treatment. As of February 2018, the province of Ontario has decided to approve DAAs for all hepatitis $\mathrm{C}$ patients, regardless of disease severity. ${ }^{39}$

\section{Québec}

Coverage excludes Holkira ${ }^{\circledR}$ Pak, Galexos ${ }^{\circledR}$, and Sunvepra ${ }^{\mathrm{TM}}$. Québec is the only province that does not participate in CADTH's common drug review process. In Québec INESSS, (Institut national d'excellence en santé et en services sociaux) is responsible for providing Health and Technology Assessments only for Québec. ${ }^{40}$

\section{Nova Scotia}

As of May 1, 2017, Nova Scotia Pharmacare will no longer approve new requests for Holkira ${ }^{\circledR}$ Pak. Nova Scotia still requires patients to have a fibrosis level of $\mathrm{F} 2$ or greater (Metavir scale or equivalent) in order to receive coverage.

\section{Prince Edward Island}

PEI provide a less liberal coverage compared to other Canadian provinces. Holkira ${ }^{\circledR}$ Pak is the only treatment approved other than PEGylated interferon and ribavirin.

\section{New Brunswick}

There is still a requirement to have a fibrosis level of F2 or greater (Metavir scale or equivalent) in order to receive treatment. New Brunswick formulary includes many DAAs for those who meet the requirements, only excluding Sunvepra ${ }^{\mathrm{TM}}$ and Holkira ${ }^{\circledR}$ Pak.

\section{Newfoundland \& Labrador}

The fibrosis level of F2 or greater (Metavir scale or equivalent) requirement still exists in Newfoundland
\& Labrador. Similar to PEI, this province has limited options for DAAs (only Daklinza ${ }^{\circledR}$ and Zepatier ${ }^{\circledR}$ ). Coverage is not available for residents of all genotypes: Daklinza ${ }^{\circledR}$ is only indicated for those with HCV genotype $1 \mathrm{~b}$ or 3 , and Zepatier ${ }^{\circledR}$ is only indicated for those with HCV genotype 1 or 4 .

\section{Yukon}

The Yukon excludes coverage for Sunvepra ${ }^{\mathrm{TM}}$, Galexos ${ }^{\circledR}$, and Vosevi ${ }^{\mathrm{TM}}$.

\section{Northwest Territories and Nunavut}

These territories follow the criteria listed under NIHB coverage. There is a wide range of DAAs listed on the NIHB formulary, only excluding Sunvepra ${ }^{\mathrm{TM}}$ and Galexos ${ }^{\circledR}$.

\section{DISCUSSION}

\section{Goals for Hepatitis C Treatment}

Many countries have set goals to eliminate $\mathrm{HCV}$ as a public health threat by a certain year. The National Health Service (NHS) in England set to eliminate HCV by $2025 .{ }^{41}$ Australia has set their goal for $2030 .{ }^{42}$ Although Canada has not yet put a strategy into place, they have recognized that policy issues must be addressed and have set a goal of treating $80 \%$ of cases by the year 2030. ${ }^{43}$ Experts say these goals are attainable but it will require intense commitment and resources to accomplish them. As previously mentioned, the WHO has created a movement called "Eliminate Hepatitis" with the goal of eliminating hepatitis B and C by 2030 in 28 countries that make up $70 \%$ of hepatitis cases globally. The 28 countries involved in this movement include Egypt, India, China, Mongolia, Nigeria, Brazil, Pakistan, Indonesia, Myanmar, Uganda, Vietnam (these 11 countries make up $50 \%$ of the global burden of hepatitis B and C) and Cambodia, Cameroon, Colombia, Ethiopia, Georgia, Kyrgyzstan, Morocco, Nepal, Peru, Philippines, Sierra Leone, South Africa, Tanzania, Thailand, Ukraine, Uzbekistan, and Zimbabwe (these 17 countries have high prevalence and are working to develop national hepatitis responses).$^{44}$ In order to reach the 2030 target, 90\% of people living with $\mathrm{CHC}$ will have to be diagnosed and $80 \%$ of those will have to be treated with DAAs. Preventive measures will also have to be put in place to reduce the number of new HCV infections. ${ }^{10}$ 


\section{Global media}

Even though these targets were set by WHO in 2016, only a few countries are currently on track to achieving them. Australia, Brazil, Egypt, Georgia, Germany, Iceland, Japan, the Netherlands and Qatar are countries that have been recognized as heading in the right direction to achieve these goals. ${ }^{45}$ Egypt has been recognized for their immense efforts in increasing screening and therefore diagnosing, as well as creating generic forms of DAAs at reduced prices for their patients. ${ }^{45}$ Brazil has recently opened up hepatitis B vaccination to the whole population, and is now reducing restrictions to DAAs, increasing hepatitis C treatment. ${ }^{45}$ As previously discussed, Australia is making immense headway by having a program of unrestricted access and supplying DAAs at reduced prices.

\section{Screening and Access to Treatment}

Not all of the estimated 71 million people globally ${ }^{1}$ affected by $\mathrm{CHC}$ are aware of their disease. Most patients are asymptomatic (and therefore undiagnosed) in the initial stages of the infection. Only when there is advanced liver damage, do patients begin to show symptoms and are more likely to be diagnosed. ${ }^{22}$ When initially infected with $\mathrm{HCV}$, most patient's immune system is unable to eradicate the virus causing up to $80 \%$ of acute infections to progress to a chronic $\mathrm{HCV}$ infection, while the rest resolve on their own without treatment. ${ }^{22}$ Because of the efficacy and safety of the new DAAs, Canadian guidelines recommend one-time population-based screening for individuals born between 1945 and 1975 (as the majority of people with hepatitis C were born in these decades) or with risk factors (such as having received a blood transfusion prior to 1992 , born or resided in HCV prevalent area, born to HCVinfected mother), and annual screening for patients with ongoing risk factors (such as IVDU, MSM, people with tattoos or body piercings done with unsterile instruments, people who have had unprotected sex with multiple partners). ${ }^{46}$ While the treatment is costly, screening is relatively inexpensive, and overall treatment of HCV is costeffective in terms of preventing the complications of HCV such as liver damage or cirrhosis ${ }^{46}$. Patients with mild fibrosis should also be candidates for DAA treatment to improve quality of life ${ }^{46}$. Canada's health care system has been defined as a "patchwork" because of the separate jurisdictional responsibilities for health in each province and territory, and at the federal level; the complexity of public and private drug coverage, and, in some cases, lack of coverage can in fact creates inequality of access to treatment. ${ }^{43}$ Nevertheless, the panCanadian Pharmaceutical Alliance, which includes provinces and territories as well as the federal government, has been successfully working to negotiate medication prices with manufacturers with the objective of making access to the newest DAAs more affordable. As discussions regarding a national Pharmacare continue, it could be anticipated that further harmonization and pricing negotitions will take place.

In order to reach WHO's 2030 goal, those at risk need to be screened, and treated if necessary. In countries with high prevalence of $\mathrm{CHC}$ and very low infection control, it is recommended by WHO that the whole population be screened if resources allow. ${ }^{47}$ In 2015 , approximately $20 \%$ of patients with $\mathrm{CHC}$ knew of their diagnosis, and only $7.4 \%$ of those diagnosed received treatment. ${ }^{1}$ Further government involvement in removing restrictions to treatment is necessary in order to meet WHO goals.

\section{CONCLUSION}

With 71 million people currently affected by $\mathrm{CHC}$ worldwide ${ }^{1}$, access to DAA treatments must improve drastically in order to reach the global goal of eradicating hepatitis $\mathrm{C}$ as a public health threat by the year 2030. In low-income countries, screening and diagnostic protocols need to be implemented, especially since treatment is now affordable for those diagnosed as generics have been created or price reductions have been negotiated. In high-income countries, where screening and diagnosis efforts are already improving, the price of DAAs needs to be negotiated in order to provide treatment to patients at an affordable price.

\section{ACKNOWLEDGMENTS AND DISCLAIMERS}

SM was supported by a summer student scholarship offered by the College of Pharmacy, Rady Faculty of Health Sciences, University of Manitoba. The financial support provided to SAS by the Leslie Buggey Professorship in Pharmacy is also gratefully acknowledged. The authors have no conflicts of interest to declare. 


\section{REFERENCES}

1. World Health Organization. July 18, 2018. Hepatitis C. Key facts. Retrieved from http://www.who.int/news-room/factsheets/detail/hepatitis-c

2. Williams D., Pitre E., Ford C., Polisena J., Weeks L. (2015) Screening for Hepatitis C Virus : A Systematic Review and Meta-analysis - Project Protocol, 1.

3. Myers, R, Shah, H, Burak K, Cooper C, Feld J. (2015) An update on the management of chronic hepatitis $\mathrm{C}$ : 2015 Consensus guidelines from the Canadian Association for the Study of the Liver. Canadian journal of gastroenterology \& hepatology. 29(2): 68

4. Katzung, B. G. Basic \& Clinical Pharmacology, 14e. Chapter 49: Antiviral Agents. July 27, 2018. Retrieved from https://accesspharmacy-mhmedicalcom.uml.idm.oclc.org/content.aspx?sectionid $=17522$ 3510\&bookid $=2249 \&$ jumpsectionID $=175223818 \&$ Resultclick=2\#1148440509

5. Vernaz, N., Girardin, F., Goossens, N., Brügger, U., Riguzzi, M., Perrier, A., Negro, F. (2016) Drug Pricing Evolution in Hepatitis C. PLos One. 11(6). Retrieved from https://www.ncbi.nlm.nih.gov/pmc/articles/PMC491 $\underline{1078 /}$

6. Lexicomp. July 26, 2018. Interferon Alfa-2b. Adverse Reactions. $\quad$ Retrieved from http://online.lexi.com.uml.idm.oclc.org/lco/action/do c/retrieve/docid/patch f/7090\#f adverse-reactions

7. Chopra, S. \& Arora, S. (2018) Patient evaluation and selection for antiviral therapy for chronic hepatitis $\mathrm{C}$ virus infection. UpToDate. Retrieved from https://www-uptodate-

com.uml.idm.oclc.org/contents/patient-evaluationand-selection-for-antiviral-therapy-for-chronic-

hepatitis-c-virus-

infection? search $=$ SVR $\% 20$ of $\% 20$ directacting $\% 20$ antivirals\&source $=$ search result\&selected Title $=1 \sim 150 \&$ usage type $=$ default\&display rank $=1$

8. Falade-Nwulia, O., Suarez-Cuervo, C., Nelson, D. R., Fried, M. W., Segal, J. B., \& Sulkowski, M. S. (2017). Oral direct-acting agent therapy for hepatitis c virus infection: A systematic review. Annals of Internal Medicine, 166(9), http://doi.org/10.7326/M16-2575

9. Iyengar, S., Tay-Teo, K., Vogler, S., Beyer, P., Wiktor, S., de Joncheere, K., \& Hill, S. (2016). Prices, Costs, and Affordability of New Medicines for Hepatitis C in 30 Countries: An Economic Analysis. PLoS Medicine, 13(5), e1002032. https://doi.org/10.1371/journal/pmed.1002032

10. World Health Organization. (2018) Progress Report on Access to Hepatitis C Treatment. Focus on overcoming barriers in low- and middle-income countries. $\quad$ Retrieved from http://apps.who.int/iris/bitstream/handle/10665/2604 45/WHO-CDS-HIV-18.4eng.pdf;jsessionid=90B7DD44E5685F71296C39EC B415F384? sequence $=1$

11. Myer, R.P., Kradjen, M., Bilodeau, M., Kaita, K, Marotta, P., Peltekian, K., Ramji, A., Estes, C., Razavi, H., Sherman, M. (2014). Burden of disease and cost of chronic hepatitis $\mathrm{C}$ virus infection in Canada. Canadian Journal of Gastroenterology and Hepatology, 28(5), 243-250.

12. Andrieux-Meyer, I., Cohn, J., de Araújo, E. S. A., \& Hamid, S. S. (2015). Disparity in market prices for hepatitis $\mathrm{C}$ virus direct-acting drugs. The Lancet Global Health, 3(11), e676-e677. https://doi.org/10/1016/S2214-109X(15)00156-4

13. de Graaff, B., Yee, K. C., Clarke, P., \& Palmer, A. (2018). Uptake of and Expenditure on Direct-Acting Antiviral Agents for Hepatitis C Treatment in Australia. Applied Health Economics and Health Policy, 16(4), 1-8. http://doi.org/10.1007/s40258018-0392-8

14. Richmond, J. A., \& Wallace, J. (2018). Implementation of hepatitis $\mathrm{C}$ cure in Australia: one year on. Journal of Virus Eradication, 4(2), 115-117. Retrieved from https://www.ncbi.nlm.nih.gov/pmc/articles/PMC589 2669/

15. The Pharmaceutical Benefits Scheme. (2018) PBS Frequently Asked Questions. Retrieved from http://www.pbs.gov.au/info/general/faq\#AmIaGener aloraConcessionalPatient

16. Hepatitis Australia. (2018) Hepatitis C Treatment. What are the new Hep C Treatments? Retrieved from https://www.hepatitisaustralia.com/hep-c-treatment/

17. Dore, G. (2017, July 31) Australia leads the world in hepatitis C treatment - what's behind its success? The Conversation. Retrieved from https://theconversation.com/australia-leads-theworld-in-hepatitis-c-treatment-whats-behind-itssuccess-81760

18. World Health Organization. (2016). Combating hepatitis B and C to reach elimination by 2030 . World Health Organization, (May), 1-16. Retrieved from http://apps.who.int/iris/bitstream/handle/10665/2064 53/WHO HIV 2016.04 eng.pdf? sequence $=1$

19. Marshall, A. D., Pawlotsky, J.-M., Lazarus, J. V., Aghemo, A., Dore, G. J., \& Grebely, J. (2018). The removal of DAA restrictions in Europe - one step closer to eliminating $\mathrm{HCV}$ as a major public health threat. Journal of Hepatology. https://doi.org/10.1016/j.jhep.2018.06.016

20. Marshall, A.D., Cunningham, E.B., Nielsen, S., Aghemo, A., Alho, H., Backmund, M.,Bruggman, P. (2018) Restrictions for reimbursement of interferonfree direct acting antiviral drugs for $\mathrm{HCV}$ infection in Europe. The Lancet Gastroenterology \& Hepatology. http://doi.org/10.1016/S2468-1253(17)30284-4 
21. Dashdorj, N., Bungert, A. S., Yagaanbuyant, D., Genden, Z., Dendev, B., Duger, D., ... Dashdorj, N. (2017) Hepatitis Prevention, Control, and Elimination Program in Mongolia: A Global Model for Eliminating Major Cancer-Causing Infectious Diseases. Retrieved from http://www.worldhepatitissummit.org/docs/defaultsource/posters/215 delgerbat-

boldbaatar.pdf?sfvrsn=2

22. Deming, P. (2017). Pharmacotherapy: A Pathophysiologic Approach, 10e. Chapter 40: Viral Hepatitis. Retrieved from https://accesspharmacymhmedical-

com.uml.idm.oclc.org/content.aspx?bookid $=1861 \& \mathrm{~s}$ ectionid $=132516044$

23. Jung, J(K)., Feldman, R., Cheong, C., Du, P. \& Leslie, D. (2016) Coverage for Hepatitis C Drugs in Medicare Part D. American Journal of Managed Care. https://www.ncbi.nlm.nih.gov/pmc/articles/PMC573 $8242 /$

24. Barua, S., Greenwald, R., Grebely, J., Dore, G. J., Swan, T., \& Taylor, L. E. (2015). Restrictions for Medicaid Reimbursement of Sofosbuvir for the Treatment of Hepatitis C Virus Infection in the United States. Annals of Internal Medicine, 163(3), 215-223. https://doi.org/10.7326/M15-0406

25. Ooka, K., Connolly, J.J. \& Lim, J.K. (2017). Medicaid Reimbursement for Oral Direct Antiviral Agents for the Treatment of Chronic Hepatitis C. The American Journal of Gastroenterology, 112, 828832. https://doi.org/10.1038/ajg.2017.87

26. Kaul, R. (2017, June 10) India develops cheap, effective treatment against Hep C, a fatal liver infection. Hindustan Times. Retrieved from https://www.hindustantimes.com/health/indiadevelops-cheap-effective-treatment-against-hep-c-afatal-liver-infection/storyUZ8nXe16VO6Gag8chPt1KO.html

27. Aggarwal, R., Chen, Q., Goel, A., Seguy, N., Pendse, R., Ayer, T., \& Chhatwal, J. (2017). Costeffectiveness of hepatitis $\mathrm{C}$ treatment using generic direct-acting antivirals available in India. PLoS ONE, 12(5), $1-15$. https://doi.org/10.1371/journal.pone.0176503

28. World Health Organization. (2016) Essential medicines and health products. Key facts on hepatitis C treatment. Retrieved from http://www.who.int/medicines/areas/access/hepCtrea t key facts/en/

29. Centers for Disease Control and Prevention (2017) Travelers' Health. Chapter 3. Infectious Diseases Related to Travel. Hepatitis C. Retrieved from https://wwwnc.cdc.gov/travel/yellowbook/2018/infe ctious-diseases-related-to-travel/hepatitis-c

30. Alcorn, T. (2018) Why Egypt Is at the Forefront of Hepatitis C Treatment. The Atlantic. Retrieved from https://www.theatlantic.com/health/archive/2018/05/ why-egypt-is-at-the-forefront-of-hepatitis-ctreatment/561305/

31. Gilead. (2016). Chronic Hepatitis C Medicines Pricing. Retrieved from http://www.gilead.com/ /media/files/pdfs/other/chro nic $\% 20$ hepatitis $\% 20 \mathrm{c} \% 20$ medicines $\% 20$ pricing $\% 20$ -\%20september\%202016.pdf

32. (n.a.) (2018) A National Canadian Hepatitis C Strategy. Canadian Hemophilia Society. Retrieved from https://www.hemophilia.ca/a-nationalcanadian-hepatitis-c-strategy/

33. CATIE. (2018) Canada's source for HIV and hepatitis $\mathrm{C}$ information. Telaprevir (Incivek). Retrieved from http://www.catie.ca/en/hepatitisc/telaprevir-incivek

34. CATIE. (2018) Canada's source for HIV and hepatitis $\mathrm{C}$ information. Boceprevir (Victrelis). Retrieved from http://www.catie.ca/en/hepatitisc/boceprevir-victrelis

35. Grant, K. (2017, February 21) Deal reduces price of life-saving hepatitis $\mathrm{C}$ drugs for Canadians. The Globe and Mail. Retrieved from https://www.theglobeandmail.com/news/national/de al-reduces-price-of-life-saving-hepatitis-c-drugs-forcanadians/article34107225/

36. CATIE. (2018) Hep C Info Update 9.9. Hepatitis C treatment restrictions removed for Alberta, Saskatchewan, Manitoba, Yukon and NIHB. Retrieved from http://www.catie.ca/en/news/hepcinfo-updates/201805-09\#article1

37. Zeuzem, S., Foster, G.R., Wang, S., Asatryan A., Gane, E., Feld, J.J. ... Mensa, F. J. (2018) Glecaprevir-Pibrentasvir for 8 or 12 Weeks in HCV Genotype 1 or 3 Infection. The New England Journal of Medicine. https://doi.org/10.1056/NEJMoa1702417

38. Hep C BC. (2018) Hepatitis C Education \& Prevention Society. Current Treatments as of March 2018. Retrieved from http://hepcbc.ca/currenttreatments/

39. Aubé, B. (2018, March 5) Provincial funding for hepatitis $\mathrm{C}$ drugs a game changer, health professionals say. $C B C$ News. Retrieved from https://www.cbc.ca/news/canada/sudbury/hepatitisc-ontario-drugs-treatment-1.4562988

40. INESSS. (2018) Institut national d'excellence en santé et en services sociaux. Mission. Retrieved from https://www.inesss.qc.ca/en/about-us/about-theinstitut.html

41. Klapper, P. E. \& Vallely, P. (2018, February 5) Can England really eliminate hepatitis $\mathrm{C}$ by 2025 ? The Conversation. Retrieved from https://theconversation.com/can-england-reallyeliminate-hepatitis-c-by-2025-90979

42. Hepatitis Australia. (2017) Australia currently on track to eliminate hepatitis C by 2030 , but challenges 
remain for hepatitis B. Retrieved from https://www.hepatitisaustralia.com/newsarticles/aust ralia-currently-on-track-to-eliminate-hepatitis-c-by2030-but-challenges-remain-for-hepatitis-

b/2/11/2017

43. Canadian Treatment Action Council. (n.d.). The time has come to eliminate hepatitis $\mathrm{C}$ in Canada. Executive Summary. Retrieved from https://ctac.ca/wpcontent/uploads/2018/02/Eliminate-hep-CExecutive-Summary.pdf

44. Department of HIV/AIDs, the Global Hepatitis Programme. (2017). World Hepatitis Day 2017. Retrieved from http://www.who.int/campaigns/hepatitisday/2017/campaign-brief.pdf

45. World Hepatitis Alliance. (2017, November 1) Only nine countries on track to eliminate hepatitis $\mathrm{C}$. Medical Xpress. Retrieved from https://medicalxpress.com/news/2017-11-countriestrack-hepatitis.html

46. Shah H, Bilodeau M, Burak KW, et al. The management of chronic hepatitis C: 2018 guideline update from the Canadian Association for the Study of the Liver. CMAJ 2018 June 4;190:E677-87. doi:10.1503/cmaj.170453/-/DC1 and Glanz, M. (2018, June 3) New guidelines recommend hepatitis C screening for those born between 1945 and 1975. The Canadian Press. Retrieved from http://www.cbc.ca/news/health/hepatitis-c-testingrecommendation-1.4690007

47. Edwards, D. J., Coppens, D. G., Prasad, T. L., Rook, L. A. \& Iyer, J. K. (2015) Access to hepatitis C medications. Bulletin of the World Health Organization.

http://dx.doi.org/10.2471/BLT.15.157784 


\section{Appendix}

Table 1: Direct-Acting Antivirals covered in Canadian jurisdictions as of August 20, 2018

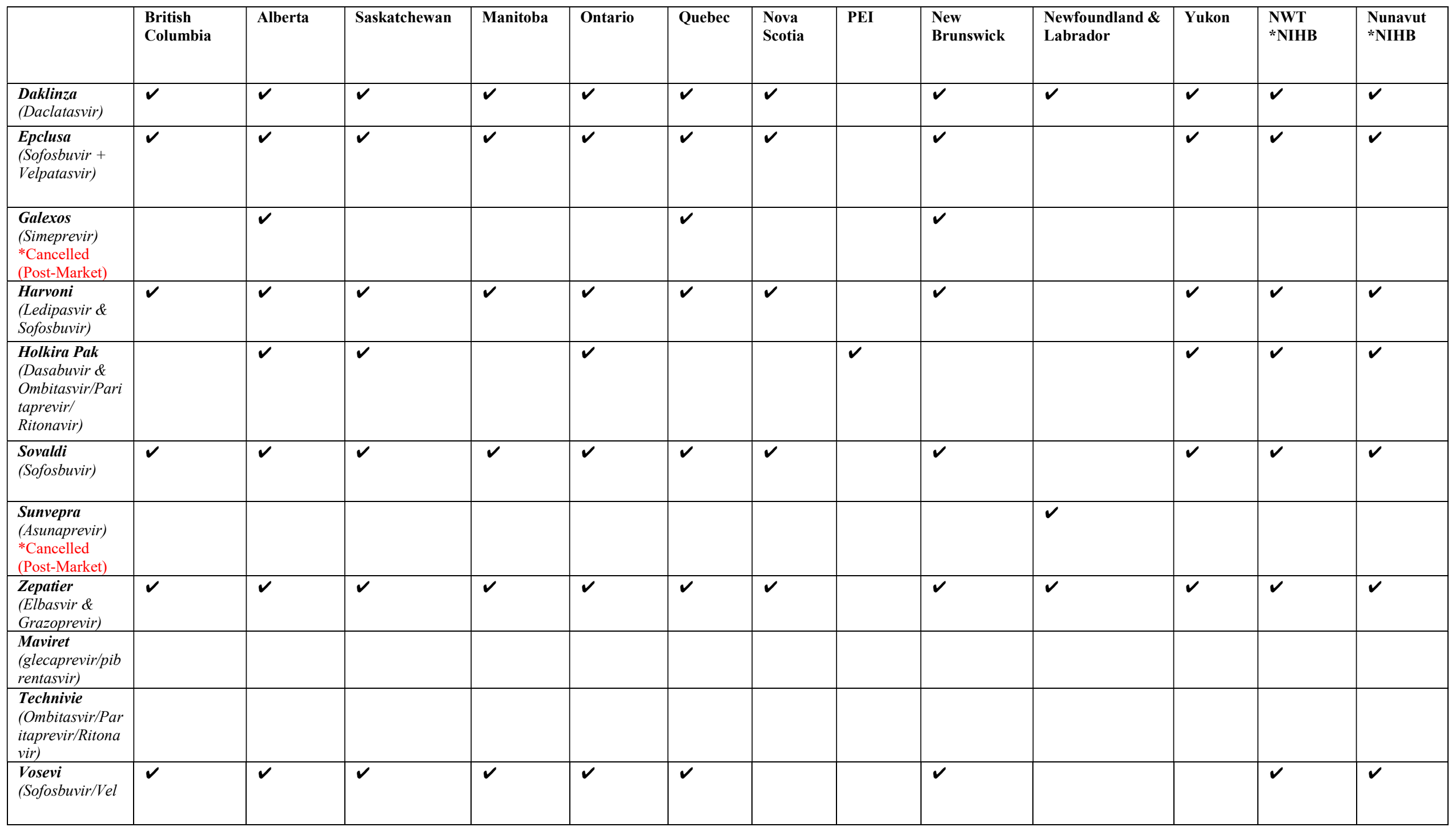




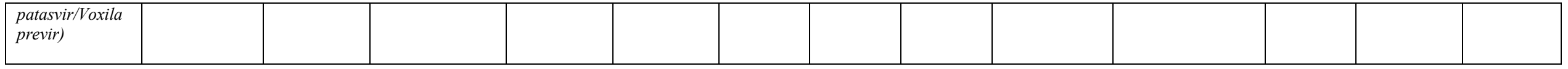

Table 2: Unit Price of Direct-Acting Antivirals in Canadian jurisdictions as of August 20, 2018

\begin{tabular}{|c|c|c|c|c|c|c|c|c|c|c|c|c|c|}
\hline & $\begin{array}{l}\text { British } \\
\text { Columbia } \\
\text { (Maximum } \\
\text { Pharmacare } \\
\text { Covers) }\end{array}$ & Alberta & Saskatchewan & Manitoba & Ontario & Quebec & $\begin{array}{l}\text { Nova } \\
\text { Scotia }\end{array}$ & PEI & $\begin{array}{l}\text { New } \\
\text { Brunswick }\end{array}$ & $\begin{array}{l}\text { Newfoundland \& } \\
\text { Labrador }\end{array}$ & Yukon & $\begin{array}{l}\text { NW } \\
\text { Territories } \\
{ }^{*} \text { NIHB }\end{array}$ & $\begin{array}{l}\text { Nunavut } \\
* \text { NIHB }\end{array}$ \\
\hline $\begin{array}{l}\text { Epclusa } \\
\text { (Sofosbuvir }+ \\
\text { Velpatasvir) }\end{array}$ & $\$ 728.5714$ & $\$ 714.2857$ & $\$ 714.2854$ & & $\$ 714.2857$ & $\$ 714.2857$ & & & $\$ 714.2857$ & $\$ 775$ & $\$ 714.29$ & & \\
\hline $\begin{array}{l}\text { Galexos } \\
\text { (Simeprevir) } \\
\text { *Cancelled } \\
\text { (Post-Market) }\end{array}$ & & $\$ 434.5500$ & & & & $\$ 434.5500$ & & & & $\$ 471.49$ & & & \\
\hline $\begin{array}{l}\text { Harvoni } \\
\text { (Ledipasvir \& } \\
\text { Sofosbuvir) }\end{array}$ & $\$ 813.5714$ & $\$ 797.6190$ & $\$ 797.6190$ & & $\$ 797.6190$ & $\$ 797.6189$ & & & $\$ 797.6189$ & $\$ 865.42$ & $\$ 797.6190$ & & \\
\hline $\begin{array}{l}\text { Holkira Pak } \\
\text { (Dasabuvir \& } \\
\text { Ombitasvir/Pari } \\
\text { taprevir/ } \\
\text { Ritonavir) }\end{array}$ & & $\$ 166.2500$ & $\$ 665.00$ & & & $\$ 665.00$ & & & $\$ 166.2500$ & & $\$ 688.5200$ & & \\
\hline $\begin{array}{l}\text { Sovaldi } \\
\text { (Sofosbuvir) }\end{array}$ & $\$ 667.8571$ & $\$ 654.7619$ & $\$ 654.7619$ & & $\$ 654.7619$ & $\$ 654.7618$ & & & $\$ 654.7618$ & $\$ 710.42$ & $\$ 654.7600$ & & \\
\hline $\begin{array}{l}\text { Sunvepra } \\
\text { (Asunaprevir) } \\
\text { *Cancelled } \\
\text { (Post-Market) }\end{array}$ & & & & & & & & & & & & & \\
\hline $\begin{array}{l}\text { Zepatier } \\
\text { (Elbasvir \& } \\
\text { Grazoprevir) }\end{array}$ & $\$ 680.2788$ & $\$ 666.94$ & $\$ 666.94$ & & $\$ 666.94$ & $\$ 666.94$ & & & $\$ 717.8671$ & $\$ 723.63$ & $\$ 666.9400$ & & \\
\hline $\begin{array}{l}\text { Maviret } \\
\text { (glecaprevir/pib } \\
\text { rentasvir) }\end{array}$ & & & & & & & & & & & & & \\
\hline $\begin{array}{l}\text { Technivie } \\
\text { (Ombitasvir/Par } \\
\text { itaprevir/Ritona } \\
\text { vir) } \\
\end{array}$ & & & & & & & & & & & & & \\
\hline
\end{tabular}




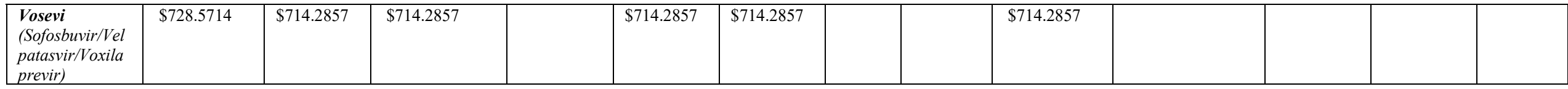

\begin{tabular}{|c|c|c|}
\hline Medication & Indication & Reimbursement Recommendation \\
\hline Daklinza (Daclatasvir) & $\begin{array}{l}\text { Chronic Hepatitis C } \\
\text { Genotype } 1,2 \text {, or } 3 \\
\text { Infection in Adults }{ }^{30}\end{array}$ & $\begin{array}{l}\text { CDEC recommends that daclatasvir, in combination with sofosbuvir, be reimbursed for the treatment of patients with genotype } 3 \\
\text { chronic hepatitis C, if the following criteria are met: } \\
\text {-Patient does not have cirrosis } \\
\text {-Prescribing restricted to hepatologists and physicians with experience treating patients with chronic hepatitis C } \\
\text {-Drug plan cost of Tx course with DCV/SOF should not exceed the drug plan cost of a Tx course with SOF plus ribavirin. } \\
\text {-Duration of treatment with DCV/SOF should be limited to } 12 \text { weeks. } \\
\text { Date of Final Recommendation: May 19, } 2016\end{array}$ \\
\hline Sovaldi (Sofosbuvir) & $\begin{array}{l}\text { Chronic Hepatitis C } \\
\text { Infection }^{31}\end{array}$ & $\begin{array}{l}\text { CDEC recommends that sofosbuvir be reimbursed for the Tx of chronic hepatitis C infection in adults with compensated liver disease, } \\
\text { including cirrhosis, if the following criteria are met: } \\
\text {-Patients with genotype } 2 \text { or } 3 \text { CHC infection, in combination with ribavirin } \\
\text {-Patients with genotype } 4 \text { CHC infection in combination with pegylated-interferon and ribavirin: For patients who have not been } \\
\text { previously treated with PR and do not have cirrosis. }{ }^{31} \\
\text { Date of Final Recommendation: May 18, } 2016\end{array}$ \\
\hline Epclusa (Sofosbuvir + Velpatasvir) & $\begin{array}{l}\text { Chronic Hepatitis C Virus } \\
\text { Infection in Adults }^{32}\end{array}$ & $\begin{array}{l}\text { CDEC recommends that sofosbuvir/velpatasvir be reimbursed for the treatment of chronic hepatitis } \mathrm{C} \text { infection, if the following criteria } \\
\text { are met: } \\
\text {-Treatment should be initiated by physicians with experience in the management of patients with } \mathrm{CHC} \text {. } \\
\text {-Reduced price. } \\
\text { Date of Final Recommendation: Oct. } 26,2016\end{array}$ \\
\hline Zepatier (Elbasvir \& Grazoprevir) & $\begin{array}{l}\text { Chronic Hepatitis C } \\
\text { Genotypes 1,3, or } 4 \\
\text { Infection in Adults }\end{array}$ & $\begin{array}{l}\text { CDEC recommends that elbasvir/grazoprevir be reimbursed for the treatment of chronic hepatitis } \mathrm{C} \text { virus genotypes } 1,3 \text {, and } 4 \\
\text { infections in adults if the following criteria are met: } \\
\text {-Treatment should be initiated by physicians with experience in the management of patients with CHC infection. } \\
\text {-Substantial reduction in price. } \\
\text { Date of Final Recommendation: May 19, } 2016\end{array}$ \\
\hline $\begin{array}{l}\text { Harvoni } \\
\text { (Ledipasvir \& Sofosbuvir) }\end{array}$ & $\begin{array}{l}\text { Chronic Hepatitis C Virus } \\
\text { Genotype } 1 \text { Infection in } \\
\text { Adults }^{34}\end{array}$ & $\begin{array}{l}\text { CDEC recommends that ledipasvir/sofosbuvir be reimbursed for the treatment of chronic hepatitis C virus genotype } 1 \text { infection in adults } \\
\text { if the following criteria are met: } \\
\text {-Treatment should be initiated by physicians with experience in the management of CHC patients } \\
\text {-Drug plan costs for ledipasvir/sofosbuvir should not exceed the drug plan costs of other interferon-free regimens for the treatment of } \\
\text { CHC. }{ }^{44} \\
\text { Date of Final Recommendation: May 18, } 2016\end{array}$ \\
\hline $\begin{array}{l}\text { Holkira Pak (Dasabuvir \& } \\
\text { Ombitasvir/Paritaprevir/ } \\
\text { Ritonavir) }\end{array}$ & $\begin{array}{l}\text { Chronic Hepatitis C Virus } \\
\text { Genotype } 1 \text { Infection in } \\
\text { Adults }^{35}\end{array}$ & $\begin{array}{l}\text { CDEC recommends that ombitasvir/paritaprevir/ritonavir and dasabuvir (OMB/PAR/RIT + DAS) be reimbursed for the treatment of } \\
\text { adults with genotype } 1 \text { chronic hepatitis } \mathrm{C} \text { virus }(\mathrm{CHC}) \text { infection, including those with compensated cirrhosis, if the following } \\
\text { conditions are met: } \\
\text {-Treatment should be initiated by physicians with experience in the management of CHC patients. } \\
\text {-Drug plan costs for (OMB/PAR/RIT + DAS) should not exceed the drug plan costs of other interferon-free regimens for the treatment } \\
\text { of CHC. }{ }^{35} \\
\text { Date of Final Recommendation: May 19, } 2016\end{array}$ \\
\hline $\begin{array}{l}\text { Sunvepra (Asunaprevir) } \\
\text { *Cancelled Post-Market }\end{array}$ & $\begin{array}{l}\text { Chronic Hepatitis C } \\
\text { Genotype } 1 \text { and } 4 \text { in } \\
\text { Adults }^{36}\end{array}$ & $\begin{array}{l}\text { CDEC recommends that asunaprevir (ASV) be reimbursed for use in combination with daclatasvir in genotype } 1 \text { b chronic hep C (CHC) } \\
\text { infection, and in combination with DCV and pegylated interferon plus ribavirin in genotype } 1 \text { and } 4 \text { CHC, provided the following } \\
\text { conditions are met: }\end{array}$ \\
\hline
\end{tabular}




\begin{tabular}{|c|c|c|}
\hline & & $\begin{array}{l}\text {-The drug plan cost of a treatment course with asunaprevir combination treatment should provide cost savings when compared with the } \\
\text { drug plan cost of a course of treatment with the least costly alternative comparable treatment option. } \\
\text {-Treatment managed by a professional with expertise in the treatment of CHC infection. }{ }^{36} \\
\text { Date of Final Recommendation: July 20, } 2016\end{array}$ \\
\hline $\begin{array}{l}\text { Galexos (Simeprevir) } \\
{ }^{*} \text { Cancelled Post-Market }\end{array}$ & 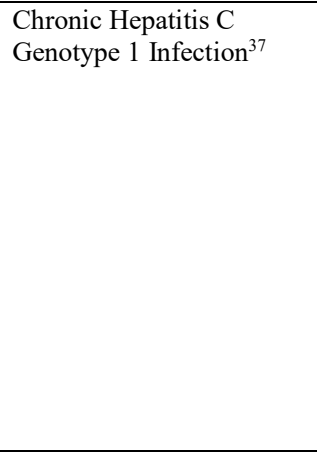 & $\begin{array}{l}\text { CDEC recommends that simeprevir, in combination with peginterferon alfa and ribavirin be listed for the treatment of CHC genotype } 1 \\
\text { infection in adults with compensated liver disease, if the following clinical critiera and conditions are met: } \\
\text { Clinical criteria: } \\
\text {-Detectable levels of HCV RNA in the last six months } \\
\text {-A fibrosis stage of F2, F3 or F4 } \\
\text {-Patients with the NS3 Q80K polymorphism should not be treated with simeprevir } \\
\text { Conditions: } \\
\text {-Patients should have their HCV strain tested for NS3 Q80K polymorphism } \\
\text {-Patients have NOT received a prior full therapeutic course of boceprevir or telaprevir } \\
\text {-Reduced price - the drug plan cost for a course of therapy with simeprevir should not exceed the drug plan cost of other currently } \\
\text { available direct-acting antiviral drugs. } \\
\text { Date of Final Recommendation: June } 18,2014\end{array}$ \\
\hline Zepatier (Elbasvir/grazoprevir) & $\begin{array}{l}\text { Chronic Hepatitis C } \\
\text { Genotypes } 1,3 \text {, or } 4 \\
\text { Infection in Adults }\end{array}$ & $\begin{array}{l}\text { CDEC recommends that elbasvir/grazoprevir be reimbursed for the treatment of chronic hepatitis } \mathrm{C} \text { virus (CHC) genotypes } 1,3 \text {, and } 4 \\
\text { infections in adults, if the following conditions are met: } \\
\text {-Treatment should be initiated by physicians with experience in the management of patients with } \mathrm{CHC} \text { infection } \\
\text {-Substantial reduction in price. }{ }^{38} \\
\text { Date of Final Recommendation: May 19, } 2016\end{array}$ \\
\hline Peginterferon Alfa-2a \& Ribavirin & $\begin{array}{l}\text { Chronic Hepatitis } \mathrm{C} \text { in } \\
\text { adult patients without } \\
\text { cirrhosis and in adult } \\
\text { patients with compensated } \\
\text { cirrhosis }^{39}\end{array}$ & $\begin{array}{l}\text { CDEC recommends that the combination of Peginterferon Alfa-2a \& Ribavirin be listed in a similar manner to other interferon plus } \\
\text { ribavirin products used in the treatment of CHC. }{ }^{39} \\
\text { Date of Final Recommendation: October 14, } 2004\end{array}$ \\
\hline Maviret (glecaprevir/pibrentasvir) & $\begin{array}{l}\text { Chronic Hepatitis C virus } \\
\text { infection }^{40}\end{array}$ & $\begin{array}{l}\text { CDEC recommends that glecaprevir/pibrentasvir be reimbursed for the treatment of adult patients with chronic hepatitis C virus (HCV) } \\
\text { genotype } 1,2,3,4,5 \text {, or } 6 \text { infection with or without compensated cirrhosis, including patients with HCV genotype } 1 \text { infection who were } \\
\text { previously treated with either a regimen of NS5A inhibitor or with a NS3/4A protease inhibitor but not both classes of inhibitors if the } \\
\text { following conditions are met: } \\
\text {-The patient is under the care of a physician with experience in the diagnosis and management of HCV infection. } \\
\text {-Drug plan cost for glecaprevir/pibrentasvir should not exceed the drug plan cost of treatment with the least costly direct-acting antiviral } \\
\text { agent(s). (DAA). }{ }^{40} \\
\text { Date of Final Recommendation: January 23, } 2018\end{array}$ \\
\hline $\begin{array}{l}\text { Technivie } \\
\text { (Ombitasvir/Paritaprevir/Ritonavir) }\end{array}$ & $\begin{array}{l}\text { Chronic Hepatitis } \mathrm{C} \text { virus } \\
\text { genotype } 4 \text { infection }^{41}\end{array}$ & $\begin{array}{l}\text { CDEC recommends that ombitasvir/paritaprevir/ritonavir be listed, in combination with ribavirin for the treatment of adults with } \\
\text { genotype } 4 \text { chronic hepatitis } \mathrm{C}(\mathrm{CHC}) \text { virus infection without cirrhosis who are either treatment-naive or were previously treated with } \\
\text { peginterferon and ribavirin, if the following conditions are met: } \\
\text {-Reduction in price to improve the cost-effectiveness to a level acceptable to the CADTH Common Drug Review (CDR)-participating } \\
\text { drug plans } \\
\text {-Under the care of a physician with expertise in the diagnosis and treatment of } \mathrm{CHC}^{41} \\
\text { Date of Final Recommendation: March 18,2016 }\end{array}$ \\
\hline $\begin{array}{l}\text { Vosevi } \\
\text { (Sofosbuvir/Velpatasvir/Voxilaprevir) }\end{array}$ & $\begin{array}{l}\text { Chronic Hepatitis C virus } \\
\text { infection }^{42}\end{array}$ & $\begin{array}{l}\text { CDEC recommends that sofosbuvir/velpatasvir/voxilaprevir be reimbursed for the treatment of adult patients with chronic hepatitis C } \\
\text { virus (HCV) infection, without cirrhosis or with compensated cirrhosis who have: genotype } 1,2,3,4,5 \text {, or } 6 \text { infection and have } \\
\text { previously been treated with an HCV regimen containing an NS5A inhibitor; or genotype } 1,2,3 \text {, or } 4 \text { infection and have been } \\
\text { previously treated with an HCV regimen containing SOF without an NS5A inhibitor, if the following conditions are met: } \\
\text {-The patient is under the care of a physician with experience in the diagnosis and management of HCV infection. } \\
\text {-Drug plan cost for sofosbuvir/velpatasvir/voxilaprevir should not exceed the drug plan cost for sofosbuvir/velpatasvir. }{ }^{42} \\
\text { Date of Final Recommendation: January 23, } 2018\end{array}$ \\
\hline
\end{tabular}


Table 4: Daklinza Coverage Criteria as of August 20, 2018

\begin{tabular}{|c|c|c|}
\hline Province & Coverage Criteria & Approved Duration \\
\hline British Columbia & $\begin{array}{l}\text { For the treatment of treatment-naïve or treatment-experienced adult } \\
\text { patients with CHC genotype } 3 \text { infection who meet ALL the following } \\
\text { critiera: } \\
\text { a) Fibrosis stage of F0 or greater (Metavir scale or equivalent) } \\
\text { b) Treatment is prescribed by a hepatologist, a } \\
\text { gastroenterologist, an infectious disease specialist, or other } \\
\text { physician experienced with treating hepatitis C } \\
\text { c) Laboratory confirmed hepatitis C genotype } 3 \\
\text { d) Laboratory confirmed quantitative HCV RNA test must be } \\
\text { done within the previous } 12 \text { months } \\
\text { e) Patient is NOT currently being treated with another } \\
\text { hepatitis C direct-acting antiviral drug (with the exception } \\
\text { of sofosbuvir) }\end{array}$ & $\begin{array}{l}\text { Treatment-naïve and treatment- } \\
\text { experienced with no cirrhosis: } 12 \\
\text { weeks in combination with sofosbuvir } \\
\text { Treatment-naïve and treatment- } \\
\text { experienced with compensated } \\
\text { cirrhosis or decompensated cirrhosis } \\
\text { OR } \\
\text { Treatment-naïve and treatment- } \\
\text { experienced liver transplant recipients } \\
\text { with no cirrhosis or with compensated } \\
\text { cirrhosis: } 12 \text { weeks in combination } \\
\text { with sofosbuvir and RBV }\end{array}$ \\
\hline Alberta & 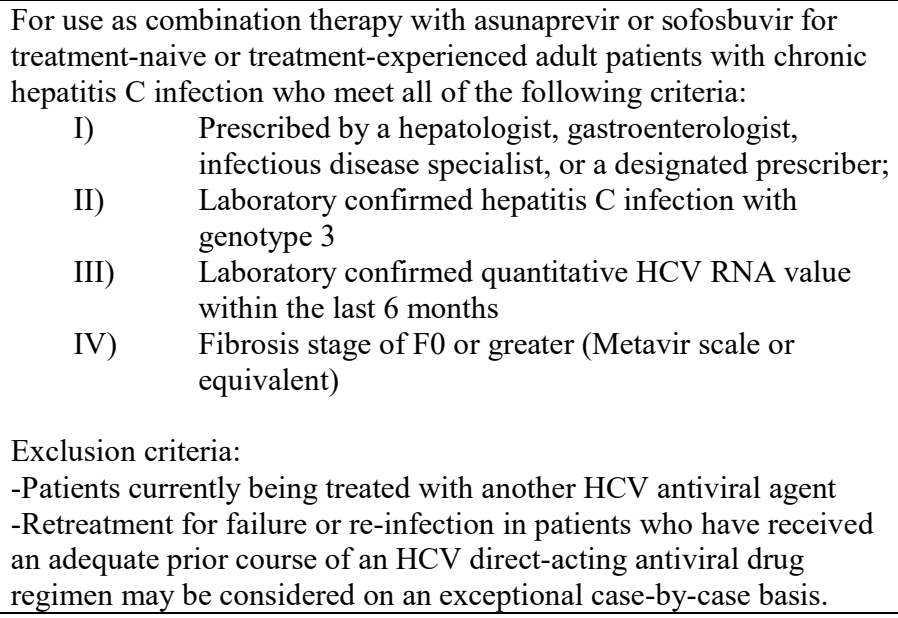 & $\begin{array}{l}\text { Treatment-naïve or treatment- } \\
\text { experienced genotype } 3 \text {, without } \\
\text { cirrhosis: } 12 \text { weeks in combination } \\
\text { with sofosbuvir }\end{array}$ \\
\hline Saskatchewan & $\begin{array}{l}\text { For use as combination therapy with sofosbuvir, alone or with } \\
\text { sofosbuvir for treatment-naive or treatment-experienced adult patients } \\
\text { with chronic hepatitis C infection who meet all of the following } \\
\text { criteria: } \\
\text { I) Prescribed by a hepatologist, gastroenterologist, infectious disease } \\
\text { specialist, or other prescriber experienced in treating hepatitis C } \\
\text { II) Laboratory confirmed hepatitis C infection with genotype 3; } \\
\text { III) Laboratory confirmed quantitative HCV RNA value within the } \\
\text { last } 6 \text { months }\end{array}$ & $\begin{array}{l}\text { Treatment naïve or treatment } \\
\text { experienced without cirrhosis: } 12 \\
\text { weeks in combination with sofosbuvir } \\
\text { Treatment-naïve or treatment- } \\
\text { experienced with compensated } \\
\text { cirrhosis or decompensated cirrhosis } \\
\text { or post-liver transplant: } 12 \text { weeks in } \\
\text { combination with sofosbuvir and } \\
\text { ribavirin }\end{array}$ \\
\hline Manitoba & $\begin{array}{l}\text { For use as combination therapy with sofosbuvir (Sovaldi) for } \\
\text { treatment naïve/experienced adult patients with chronic hepatitis C } \\
\text { infection who meet ALL of the following criteria: } \\
\begin{array}{cl}\text { i) } & \text { Treatment is prescribed by a hepatologist, } \\
& \text { gastroenterologist, or infectious disease specialist } \\
\text { ii) } & \text { Laboratory confirmed hepatitis C infection with } \\
& \text { genotype } 3 \\
\text { iii) } & \text { Patient has a quantitative HCV RNA value within the } \\
& \text { last } 6 \text { months } \\
\text { iv) } & \text { Fibrosis stage (2) of F0 or greater (Metavir scale or } \\
& \text { equivalent) (As of April 2018) }\end{array}\end{array}$ & $\begin{array}{l}\text { Treatment regimens for Daklinza for } \\
\text { genotype } 3 \text { and duration of therapy } \\
\text { reimbursed: } \\
\text {-Genotype } 3 \text { patient population } \\
\text { duration of therapy: } \\
\text {-Treatment-naïve or treatment- } \\
\text { experienced without cirrhosis - } 12 \\
\text { weeks in combination with sofosbuvir } \\
\text {-Treatment-naïve or treatment- } \\
\text { experienced with compensated } \\
\text { cirrhosis (5); or decompensated } \\
\text { cirrhosis (5); or post-liver transplant - } \\
12 \text { weeks in combination with } \\
\text { sofosbuvir and ribavirin } \\
\text { *Retreatment for failure or re- } \\
\text { infection in patients who have } \\
\text { received an adequate prior course of }\end{array}$ \\
\hline
\end{tabular}




\begin{tabular}{|c|c|c|}
\hline & & $\begin{array}{l}\text { direct-acting antiviral will be } \\
\text { considered on a case-by-case basis. }\end{array}$ \\
\hline Ontario & $\begin{array}{l}\text { For use as combination therapy with sofosbuvir, alone or with } \\
\text { sofosbuvir for treatment-naive or treatment-experienced adult patients } \\
\text { with chronic hepatitis C infection who meet all of the following } \\
\text { criteria: } \\
\text { I) Prescribed by a hepatologist, gastroenterologist, infectious disease } \\
\text { specialist, or other prescriber experienced in treating hepatitis C } \\
\text { II) Laboratory confirmed hepatitis C infection with genotype 3; } \\
\text { III) Laboratory confirmed quantitative HCV RNA value within the } \\
\text { last } 6 \text { months }\end{array}$ & $\begin{array}{l}\text { Treatment-naïve or treatment- } \\
\text { experienced without cirrhosis: } 12 \\
\text { weeks in combination with sofosbuvir } \\
\text { (Sovaldi) } \\
\text { Treatment-naïve or treatment- } \\
\text { experienced with compensated } \\
\text { cirrhosis or decompensated cirrhosis } \\
\text { or post liver transplant: } 12 \text { weeks in } \\
\text { combination with sofosbuvir } \\
\text { (Sovaldi) and ribavirin (Ibavyr) } \\
\text { * Retreatment is not funded. } \\
\text { Retreatment for failure or re-infection } \\
\text { in patients who have received an } \\
\text { adequate prior course of direct-acting } \\
\text { antiviral will be considered on a case- } \\
\text { by case basis through the Exceptional } \\
\text { Access Program. }\end{array}$ \\
\hline Quebec & $\begin{array}{l}\text { In association with sofosbuvir, for treatment of persons suffering } \\
\text { from chronic hepatitis } C \text { genotype } 3 \text { without cirrhosis: } \\
\text {-Who have a contraindication or a serious intolerance to pegylated } \\
\text { interferon alfa or ribavirin } \\
\text { Or } \\
\text {-Who have experienced a therapeutic failure with an association }\end{array}$ & 12 weeks \\
\hline Nova Scotia & $\begin{array}{l}\text { For treatment-naïve or treatment-experienced adult patients with } \\
\text { chronic hepatitis C virus (HCV) who meet the following criteria: } \\
\text { i) Must be prescribed by a hepatologist, gastroenterologist, or } \\
\text { infectious disease specialist (or other physician experienced } \\
\text { in treating a patient with hepatitis C infection) } \\
\text { ii) Lab-confirmed hepatitis C genotype } 3 \\
\text { iii) Quantitative HCV RNA value within the last } 6 \text { months } \\
\text { iv) Fibrosis stage must be provided }\end{array}$ & $\begin{array}{l}\text { Without cirrhosis: } 12 \text { weeks in } \\
\text { combination with sofosbuvir } \\
\text { With compensated or decompensated } \\
\text { cirrhosis, or post-liver transplant with } \\
\text { no cirrhosis or with compensated } \\
\text { cirrhosis: } 12 \text { weeks in combination } \\
\text { with sofosbuvir and ribavirin }\end{array}$ \\
\hline PEI & N/A & $\mathrm{N} / \mathrm{A}$ \\
\hline New Brunswick & $\begin{array}{l}\text { For treatment-naïve or treatment-experienced adult patients with } \\
\text { chronic hepatitis C virus (HCV) who meet the following criteria: } \\
\text {-Must be prescribed by a hepatologist, gastroenterologist, or } \\
\text { infectious disease specialist (or other physician experienced in } \\
\text { treating a patient with hepatitis C infection) } \\
\text {-Lab-confirmed hepatitis C genotype } 3 \\
\text {-Quantitative HCV RNA value within the last } 6 \text { months } \\
\text {-Fibrosis stage }\end{array}$ & $\begin{array}{l}\text { Without cirrhosis: } 12 \text { weeks in } \\
\text { combination with sofosbuvir } \\
\text { With compensated or decompensated } \\
\text { cirrhosis or post-liver transplant with } \\
\text { no cirrhosis or with compensated } \\
\text { cirrhosis: } 12 \text { weeks in combination } \\
\text { with sofosbuvir and ribavirin }\end{array}$ \\
\hline $\begin{array}{l}\text { Newfoundland \& } \\
\text { Labrador }\end{array}$ & $\begin{array}{l}\text { For treatment-naïve or treatment-experienced adult patients with } \\
\text { chronic hepatitis C virus (HCV) who meet the following criteria: } \\
\text {-Prescribed by a hepatologist, gastroenterologist, or infectious disease } \\
\text { specialist (or other prescribers with expertise in the treatment of } \\
\text { hepatitis C infection) } \\
\text {-Lab-confirmed hepatitis C genotype } 1 \mathrm{~b} \text { and } 3 \\
\text {-Quantitative HCV RNA value within the last } 6 \text { months } \\
\text {-Fibrosis stage F2 or greater (Metavir scale or equivalent) or Fibrosis } \\
\text { stage less than F2 at least one of the following poor prognostic } \\
\text { factors: } \\
\text {-Co-infected with HIV or hepatitis B virus } \\
\text {-Post-organ transplant (liver and/or non-liver transplant) } \\
\text {-Extra-hepatic manifestations }\end{array}$ & $\begin{array}{l}\text { Genotype 1b: } \\
\text {-Without cirrhosis or with } \\
\text { compensated cirrhosis: } 24 \text { weeks in } \\
\text { combination with asunaprevir } \\
\text { Genotype 3: } \\
\text {-Without cirrhosis: } 12 \text { weeks in } \\
\text { combination with sofosbuvir } \\
\text {-With compensated or decompensated } \\
\text { cirrhosis or post-liver transplant with } \\
\text { no cirrhosis or with compensated } \\
\text { cirrhosis: } 12 \text { weeks in combination } \\
\text { with sofosbuvir and ribavirin }\end{array}$ \\
\hline
\end{tabular}




\begin{tabular}{|c|c|c|}
\hline & $\begin{array}{l}\text {-Chronic kidney disease stage } 3,4 \text {, or } 5 \text { as defined by the National } \\
\text { Kidney Foundation Kidney Disease Outcomes Quality Initiative } \\
\text {-Co-existent liver disease with diagnostic evidence of fatty liver } \\
\text { disease (e.g., non-alcoholic steatohepatitis) } \\
\text {-Patients with diabetes being treated with antihyperglycemic } \\
\text { medications } \\
\text {-Woman of childbearing age who is planning a pregnancy within } \\
\text { the next } 12 \text { months }\end{array}$ & \\
\hline Yukon & $\begin{array}{l}\text { For treatment-naïve or treatment-experienced* adult patients with } \\
\text { chronic hepatitis C infection at any fibrosis stage (F0-F4) who meet } \\
\text { ALL of the following criteria: } \\
\text { i) Treatment is prescribed by a hepatologist, infectious disease } \\
\text { specialist or gastroenterologist } \\
\text { ii) Laboratory confirmed hepatitis C genotype } 1,2,3,4,5,6 \text {, } \\
\text { or mixed genotype } \\
\text { iii) Laboratory confirmed quantitative HCV RNA level taken } \\
\text { in the last } 12 \text { months } \\
\text { Retreatment for failure or re-infection in patients who have received } \\
\text { an adequate prior course of direct-acting antivirals will be considered } \\
\text { on a case-by-case basis under the formulary exception process. } \\
\text { All exception requests should include: } \\
\text {-Lab-confirmed hepatitis C genotype } \\
\text {-Quantitative HCV RNA value within the last } 12 \text { months } \\
\text {-Fibrosis stage } \\
\text { *Treatment-experienced is defined as those who have been previously } \\
\text { treated with a PegIFN/RBV regimen (including regimens containing } \\
\text { an HCV protease inhibitor), and have not experienced an adequate } \\
\text { response. }\end{array}$ & $\mathrm{N} / \mathrm{A}$ \\
\hline $\begin{array}{l}\text { NWT, Nunavut } \\
\text { *NIHB }\end{array}$ & $\begin{array}{l}\text { For adult patients with chronic hepatitis } \mathrm{C} \text { infection at any fibrosis } \\
\text { stage (F0-F4) who meet ALL of the following criteria: } \\
\text { I) Prescribed by a hepatologist, gastroenterologist, infectious disease } \\
\text { specialist, or other prescriber experienced in treating hepatitis } \mathrm{C} \\
\text { II) Laboratory confirmed hepatitis C infection with genotype } 1,2,3 \text {, } \\
4,5,6 \text {, or mixed genotype; } \\
\text { III) Laboratory confirmed quantitative HCV RNA value within the } \\
\text { last } 12 \text { months } \\
\text { * Retreatment for failure or re-infection in patients who have received } \\
\text { an adequate prior course of direct-acting antivirals will be considered } \\
\text { on a case-by-case basis. }\end{array}$ & $\mathrm{N} / \mathrm{A}$ \\
\hline
\end{tabular}


Table 5: Epclusa Coverage Criteria as of August 20, 2018

\begin{tabular}{|c|c|c|}
\hline Province & Coverage Criteria & Approved Duration \\
\hline $\begin{array}{l}\text { British } \\
\text { Columbia }\end{array}$ & $\begin{array}{l}\text { For the treatment of treatment-naïve or treatment-experienced adult } \\
\text { patients with CHC genotype } 1,2,3,4,5,6 \text {, or mixed genotype } \\
\text { infection who meet ALL of the following criteria: } \\
\text { a) Fibrosis stage of F0 or greater (Metavir scale or } \\
\text { equivalent). Special Authority requests for patients must } \\
\text { include a fibrosis score test performed in the last } 12 \\
\text { months. Acceptable methods include liver biopsy, transient } \\
\text { elastography (FibroScan) and serum biomarker panels } \\
\text { (AST-to-Platelet Ratio Index (APRI)) either alone or in } \\
\text { combination. Supporting documentation must be submitted. } \\
\text { Treatment is prescribed by a hepatologist, a } \\
\text { gastroenterologist, an infectious disease specialist, or other } \\
\text { physician experienced with treating hepatitis C. } \\
\text { Laboratory confirmed hepatitis C genotype 1, 2, 3, 4, 5, or } \\
6 \\
\text { d) Laboratory confirmed quantitative HCV RNA test must be } \\
\text { done within the previous } 12 \text { months } \\
\text { Patient is NOT currently being treated with another hepatitis C direct- } \\
\text { acting antiviral drug }\end{array}$ & $\begin{array}{l}\text { Treatment-naïve and treatment- } \\
\text { experienced with no cirrhosis or with } \\
\text { compensated cirrhosis: } 12 \text { weeks } \\
\text { Treatment-naïve and treatment- } \\
\text { experienced with decompensated } \\
\text { cirrhosis: } 12 \text { weeks with RBV }\end{array}$ \\
\hline $\begin{array}{l}\text { Alberta, NWT \& } \\
\text { Nunavut }\end{array}$ & $\begin{array}{l}\text { For adult patients with chronic hepatitis C infection at any fibrosis } \\
\text { stage (F0-F4) who meet ALL of the following criteria: } \\
\text { I) Prescribed by a hepatologist, gastroenterologist, infectious disease } \\
\text { specialist, or other prescriber experienced in treating hepatitis C } \\
\text { II) Laboratory confirmed hepatitis C infection with genotype } 1,2,3 \text {, } \\
\text { 4, 5, 6, or mixed genotype; } \\
\text { III) Laboratory confirmed quantitative HCV RNA value within the } \\
\text { last 6-12 months } \\
\text { * Retreatment for failure or re-infection in patients who have received } \\
\text { an adequate prior course of direct-acting antivirals will be considered } \\
\text { on a case-by-case basis. }\end{array}$ & $\begin{array}{l}\text { Alberta: } \\
\text {-Treatment-naive or treatment- } \\
\text { experienced, without cirrhosis or with } \\
\text { compensated cirrhosis: } 12 \text { weeks } \\
\text { - Treatment-naive or treatment- } \\
\text { experienced, with decompensated } \\
\text { cirrhosis: } 12 \text { weeks in combination with } \\
\text { ribavirin }\end{array}$ \\
\hline Saskatchewan & $\begin{array}{l}\text { For use as monotherapy or as combination therapy with ribavirin for } \\
\text { treatment-naïve or treatment-experienced adult patients with chronic } \\
\text { hepatitis C infection according to the following criteria: } \\
\text { i) Treatment is prescribed by a hepatologist, } \\
\text { gastroenterologist, an infectious disease specialist or other } \\
\text { prescriber experienced in treatment hepatitis C } \\
\text { Laboratory-confirmed hepatitis C genotype 1, 2, 3, 4, } \\
\text { ii) } 5,6 \text {, or mixed genotypes } \\
\text { Laboratory-confirmed quantitative HCV RNA value } \\
\text { iii) within the last } 6 \text { months }\end{array}$ & $\begin{array}{l}\text { Treatment-naïve or treatment- } \\
\text { experienced without cirrhosis or with } \\
\text { compensated cirrhosis: } 12 \text { weeks } \\
\text { Treatment-naïve or treatment- } \\
\text { experienced with decompensated } \\
\text { cirrhosis: } 12 \text { weeks in combination with } \\
\text { ribavirin }\end{array}$ \\
\hline Manitoba & $\begin{array}{l}\text { For treatment-naïve or treatment-experienced adult patients with } \\
\text { chronic hepatitis C genotype } 1,2,3,4,5,6 \text {, or mixed genotypes } \\
\text { infection who meet ALL of the following: } \\
\text { i) Treatment is prescribed by a hepatologist, } \\
\text { gastroenterologist, or infectious disease specialist } \\
\text { ii) Laboratory confirmed hepatitis C genotype } 1,2,3,4,5,6 \text {, } \\
\text { or mixed genotypes } \\
\text { iii) Patient has a quantitative HCV RNA value within the last } 6 \\
\text { months } \\
\text { iv) Fibrosis (2) stage of F0 or greater Metavir scale or } \\
\text { equivalent (as of April 2018) }\end{array}$ & $\begin{array}{l}\text { Duration of therapy reimbursed: } \\
\text { Genotype } 1,2,3,4,5,6 \text { or mixed } \\
\text { patient population duration of therapy: } \\
\text {-Treatment-naïve or treatment- } \\
\text { experienced non-cirrhotic or } \\
\text { compensated cirrhosis }(5)-12 \text { weeks } \\
\text {-Treatment-naïve or treatment- } \\
\text { experienced with decompensated } \\
\text { cirrhosis (5) - } 12 \text { weeks in combination } \\
\text { with ribavirin } \\
\text { *Retreatment for failure or re-infection } \\
\text { in patients who have received an } \\
\text { adequate prior course of direct-acting } \\
\text { antiviral will be considered on a case- } \\
\text { by-case basis }\end{array}$ \\
\hline Ontario & $\begin{array}{l}\text { For treatment-naive or treatment-experienced adult patients with } \\
\text { chronic hepatitis } \mathrm{C} \text { infection who meet all of the following criteria: }\end{array}$ & $\begin{array}{l}\text {-Treatment-naive or treatment- } \\
\text { experienced, without cirrhosis or with }\end{array}$ \\
\hline
\end{tabular}




\begin{tabular}{|c|c|c|}
\hline & $\begin{array}{l}\text { I) Prescribed by a hepatologist, gastroenterologist, infectious disease } \\
\text { specialist, or a designated prescriber; } \\
\text { II) Laboratory confirmed hepatitis C genotype } 1,2,3,4,5,6 \text { or } \\
\text { mixed genotypes; } \\
\text { III) Laboratory confirmed quantitative HCV RNA value within the } \\
\text { last } 6 \text { months }\end{array}$ & $\begin{array}{l}\text { compensated cirrhosis: } 12 \text { weeks } \\
\text { - Treatment-naive or treatment- } \\
\text { experienced, with decompensated } \\
\text { cirrhosis: } 12 \text { weeks in combination with } \\
\text { ribavirin (Ibavyr) }\end{array}$ \\
\hline Quebec & $\begin{array}{l}\text { In association with ribavirin, for treatment of persons suffering from } \\
\text { chronic hepatitis } \mathrm{C} \text { with decompensated cirrhosis } \\
\text { OR } \\
\text { As monotherapy, for treatment of persons suffering from chronic } \\
\text { hepatitis C without decompensated cirrhosis }\end{array}$ & $\begin{array}{l}\text { Those with decompensated cirrhosis: } 12 \\
\text { weeks in association with ribavirin } \\
\text { Those without decompensated cirrhosis: } \\
12 \text { weeks as monotherapy }\end{array}$ \\
\hline Nova Scotia & $\begin{array}{l}\text { For treatment-naïve or treatment-experienced adult patients with } \\
\text { chronic hepatitis C virus (HCV) who meet the following criteria: } \\
\text {-Must be prescribed by a hepatologist, gastroenterologist, or } \\
\text { infectious disease specialist (or other physician experienced in } \\
\text { treating a patient with hepatitis C infection) } \\
\text {-Lab-confirmed hepatitis C genotype } 1,2,3,4,5,6 \text {, or mixed } \\
\text { genotypes } \\
\text {-Quantitative HCV RNA value within the last } 6 \text { months } \\
\text {-Fibrosis stage must be provided }\end{array}$ & $\begin{array}{l}\text {-Patients with compensated cirrhosis or } \\
\text { without cirrhosis: } 12 \text { weeks } \\
\text {-Patients with decompensated cirrhosis: } \\
12 \text { weeks in combination with ribavirin }\end{array}$ \\
\hline $\begin{array}{l}\text { PEI, } \\
\text { Newfoundland } \\
\text { \& Labrador }\end{array}$ & N/A & $\mathrm{N} / \mathrm{A}$ \\
\hline New Brunswick & $\begin{array}{l}\text { For treatment-naïve or treatment-experienced adult patients with } \\
\text { chronic hepatitis C virus (HCV) who meet the following criteria: } \\
\text { For treatment-naïve or treatment-experienced adult patients with } \\
\text { chronic hepatitis C virus (HCV) who meet the following criteria: } \\
\text {-Must be prescribed by a hepatologist, gastroenterologist, or } \\
\text { infectious disease specialist (or other physician experienced in } \\
\text { treating a patient with hepatitis C infection) } \\
\text {-Lab-confirmed hepatitis C genotype } 1,2,3,4,5,6 \text { or mixed } \\
\text { genotypes } \\
\text {-Quantitative HCV RNA value within the last } 6 \text { months } \\
\text {-Fibrosis stage }\end{array}$ & $\begin{array}{l}\text { Patients with compensated cirrhosis or } \\
\text { without cirrhosis: } 12 \text { weeks } \\
\text { Patients with decompensated cirrhosis: } \\
12 \text { weeks in combination with ribavirin }\end{array}$ \\
\hline Yukon & $\begin{array}{l}\text { For treatment-naïve or treatment-experienced* adult patients with } \\
\text { chronic hepatitis C infection at any fibrosis stage (F0-F4) who meet } \\
\text { ALL of the following criteria: } \\
\text { i) Treatment is prescribed by a hepatologist, infectious } \\
\text { disease specialist or gastroenterologist } \\
\text { ii) Laboratory confirmed hepatitis C genotype } 1,2,3,4,5,6 \text {, } \\
\text { or mixed genotype } \\
\text { iii) Laboratory confirmed quantitative HCV RNA level taken } \\
\text { in the last } 12 \text { months } \\
\text { Retreatment for failure or re-infection in patients who have received } \\
\text { an adequate prior course of direct-acting antivirals will be considered } \\
\text { on a case-by-case basis under the formulary exception process. } \\
\text { All exception requests should include: } \\
\text {-Lab-confirmed hepatitis C genotype } \\
\text {-Quantitative HCV RNA value within the last } 12 \text { months } \\
\text {-Fibrosis stage } \\
\text { *Treatment-experienced is defined as those who have been } \\
\text { previously treated with a PegIFN/RBV regimen (including regimens } \\
\text { containing an HCV protease inhibitor), and have not experienced an } \\
\text { adequate response. }\end{array}$ & N/A \\
\hline
\end{tabular}


Table 6: Sunvepra Coverage Criteria as of August 20, 2018

\begin{tabular}{|c|c|c|}
\hline Province & Coverage Criteria & Approved Duration \\
\hline $\begin{array}{l}\text { Newfoundland \& } \\
\text { Labrador }\end{array}$ & $\begin{array}{l}\text { For treatment-naïve or treatment-experienced adult patients with } \\
\text { chronic hepatitis C virus (HCV) who meet the following criteria: } \\
\text { I) Prescribed by a hepatologist, gastroenterologist, infectious disease } \\
\text { specialist, or a designated prescriber; } \\
\text { II) Laboratory confirmed hepatitis C infection with genotype } 1 \mathrm{~b} \text {; } \\
\text { III) Laboratory confirmed quantitative HCV RNA value within the } \\
\text { last } 6 \text { months; } \\
\text { IV) Fibrosis stage of F2 or greater (Metavir scale or equivalent); } \\
\text { OR Fibrosis stage less than F2 and at least one of the following poor } \\
\text { prognostic factors: } \\
\text {-Co-infected with HIV or HBV } \\
\text {-Post-organ transplant (liver and/or non-liver transplant) } \\
\text {-Extra-hepatic manifestations } \\
\text {-Chronic kidney disease stage } 3 \text {, } 4 \text {, or } 5 \text { as defined by the National } \\
\text { Kidney Foundation Kidney Disease Outcomes Quality Initiative } \\
\text {-Co-existent liver disease with diagnostic evidence of fatty liver } \\
\text { disease (e.g. non-alcoholic steatohepatitis) } \\
\text {-Patients with diabetes being treated with antihyperglycemic } \\
\text { medications } \\
\text {-Woman of childbearing age who is planning a pregnancy within } \\
\text { the next } 12 \text { months }\end{array}$ & $\begin{array}{l}\text { Without cirrhosis or with compensated } \\
\text { cirrhosis: } 24 \text { weeks in combination } \\
\text { with daclatasvir }\end{array}$ \\
\hline $\begin{array}{l}\text { British Columbia, } \\
\text { Alberta, } \\
\text { Saskatchewan, } \\
\text { Manitoba, } \\
\text { Ontario, Quebec, } \\
\text { Nova Scotia, PEI, } \\
\text { New Brunswick, } \\
\text { Yukon, NWT \& } \\
\text { Nunavut }\end{array}$ & N/A & $\mathrm{N} / \mathrm{A}$ \\
\hline
\end{tabular}

Table 7: Galexos Coverage Criteria as of August 20, 2018

\begin{tabular}{|c|c|c|}
\hline Province & Coverage Criteria & Approved Duration \\
\hline Alberta & $\begin{array}{l}\text { For use in combination with peginterferon alfa/ribavirin, for the } \\
\text { treatment of genotype } 1 \text { chronic hepatitis } \mathrm{C}(\mathrm{CHC}) \text { in adults with } \\
\text { compensated liver disease and detectable levels of hepatitis } \mathrm{C} \text { virus } \\
\text { (HCV) RNA in the last } 6 \text { months, and a fibrosis stage of F2, F3, or } \\
\text { F4 and; who have either not received previous therapy with } \\
\text { peginterferon alfa/ribavirin or have failed previous therapy with } \\
\text { peginterferon alfa/ribavirin following prior null response, partial } \\
\text { response or relapse. } \\
\text { Cover cannot be considered for: } \\
\text {-Treatment of CHC other than genotype } 1 \\
\text {-Treatment as monotherapy } \\
\text {-patients with the NS3 Q80K polymorphism } \\
\text {-Patients with decompensated liver disease, including a history of the } \\
\text { presence of clinical ascites, bleeding varices or hepatic } \\
\text { encephalopathy } \\
\text {-Patients who previously received a prior full therapeutic course with } \\
\text { an HCV NS3/4A protease inhibitor } \\
\text {-Extensions beyond the stated duration } \\
\text { Failure of previous therapy with peginterferon alfa/ribavirin is } \\
\text { defined as: } \\
\text {-Prior null response: less than } 2 \text { logs (100 fold) reduction in HCV } \\
\text { RNA after } 12 \text { weeks of treatment }\end{array}$ & $\begin{array}{l}\text { Initial approval period: } \\
\text {-All patients may receive an initial } \\
\text { approval for } 6 \text { weeks of treatment } \\
\text { coverage ( } 6 \text { weeks of simeprevir in } \\
\text { combination with peginterferon } \\
\text { alfa/ribavirin) } \\
\text { Renewal approval periods: } \\
\text {-Total of } 12-48 \text { weeks treatment } \\
\text { duration depending on HCV RNA } \\
\text { levels }\end{array}$ \\
\hline
\end{tabular}




\begin{tabular}{|c|c|c|}
\hline & $\begin{array}{l}\text {-Partial response: a decrease in HCV RNA viral load greater than or } \\
\text { equal to } 2 \text { logs ( } 100 \text { fold) by treatment week 12, but failure to } \\
\text { achieve a sustained virologic response (SVR) } \\
\text {-Relapse: undetectable HCV RNA at end of previous therapy with } \\
\text { subsequently detectable HCV RNA } \\
\text { *This was effective April 1, 2018, but as of April 27, 2018, Alberta } \\
\text { has removed the fibrosis requirement in order for DAA coverage. }\end{array}$ & \\
\hline Quebec & $\begin{array}{l}\text { In association with ribavirin and pegylated interferon alfa for } \\
\text { treatment of persons suffering from chronic hepatitis C genotype 1, } \\
\text { without a Q80K mutation, who are not HIV-1 infected, and who have } \\
\text { already experienced a therapeutic failure with a combination of } \\
\text { ribavirin / pegylated interferon alfa. }\end{array}$ & $\begin{array}{l}\text { Authorization is granted for } 12 \text { weeks } \\
\text { The total duration of treatment, } \\
\text { including the concomitant and } \\
\text { subsequent taking of the combination } \\
\text { of ribavirin/pegylated interferon alfa, } \\
\text { will be } 48 \text { weeks if the viral load } \\
\text { (HCV-RNA) is undetectable on } \\
\text { treatment week } 24 \text {. }\end{array}$ \\
\hline New Brunswick & $\begin{array}{l}\text { For the treatment of chronic hepatitis C genotype } 1 \text { infection in adult } \\
\text { patients with compensated liver disease, in combination with } \\
\text { peginterferon alpha and RBV when all of the following criteria are } \\
\text { met: } \\
\text { i) Detectable levels of HCV RNA in the last } 6 \text { months } \\
\text { ii) } \quad \text { equivalent) } \\
\text { Exclusion Criteria: } \\
\text { - Patients with the NS3 Q80K polymorphism should not be } \\
\text { treated with simeprevir } \\
\text { Patients who have received a prior full therapeutic course } \\
\text { of boceprevir or telaprevir in combination with } \\
\text { PegIFN/RBV and did not receive an adequate response } \\
\text { Decompensated liver disease } \\
\text { Patients less than } 18 \text { years old } \\
\text { Patients who have had prior organ transplant including } \\
\text { liver transplant } \\
\text { Simeprevir in combination with sofosbuvir }\end{array}$ & $\begin{array}{l}\text { Only one course of treatment (for up to } \\
12 \text { weeks duration) will be approved }\end{array}$ \\
\hline $\begin{array}{l}\text { British Columbia, } \\
\text { Saskatchewan, } \\
\text { Manitoba, } \\
\text { Ontario, Nova } \\
\text { Scotia, PEI, } \\
\text { Newfoundland \& } \\
\text { Labrador, } \\
\text { Yukon, NWT \& } \\
\text { Nunavut }\end{array}$ & N/A & N/A \\
\hline
\end{tabular}


Table 8: Harvoni Coverage Criteria as of August 20, 2018

\begin{tabular}{|c|c|c|}
\hline Province & Coverage Criteria & Approved Duration \\
\hline British Columbia & $\begin{array}{l}\text { For the treatment of treatment-naïve or treatment-experienced adult } \\
\text { patients with CHC genotype } 1 \text { infection who meet ALL the following } \\
\text { criteria: } \\
\text { a) Fibrosis stage of F0 or greater (Metavir scale or equivalent) } \\
\text { Special Authority requests for patients must include a } \\
\text { fibrosis score test performed in the last } 12 \text { months. } \\
\text { Acceptable methods include liver biopsy, transient } \\
\text { elastography (FibroScan) and serum biomarker panels } \\
\text { (AST-to-Platelet Ratio Index (APRI) either alone or in } \\
\text { combination. Supporting documentation must be } \\
\text { submitted. } \\
\text { b) Treatment is prescribed by a hepatologist, a } \\
\text { gastroenterologist, an infectious disease specialist, or other } \\
\text { physicians experienced with treating hepatitis C } \\
\text { c) Laboratory confirmed hepatitis C genotype 1 } \\
\text { d) Laboratory confirmed quantitative HCV RNA test must be } \\
\text { done within the previous } 12 \text { months } \\
\text { Patient is NOT currently being treated with another hepatitis C } \\
\text { direct-acting antiviral drug }\end{array}$ & $\begin{array}{l}\text { Treatment-naïve with no cirrhosis, who } \\
\text { have pre-treatment HCV RNA level } \\
6 \text { million IU/mL: } 8 \text { or } 12 \text { weeks } \\
\text { Treatment naïve with no cirrhosis, who } \\
\text { have pre-treatment HCV RNA level } \geq \\
6 \text { million IU/mL: } 12 \text { weeks } \\
\text { Treatment-naïve with compensated } \\
\text { cirrhosis: } 12 \text { weeks } \\
\text { Treatment-experienced with no } \\
\text { cirrhosis: } 12 \text { weeks } \\
\text { Treatment-naïve or treatment- } \\
\text { experienced HCV/HIV-1 co-infected } \\
\text { with no cirrhosis or with compensated } \\
\text { cirrhosis: } 12 \text { weeks } \\
\text { Treatment-experienced with } \\
\text { compensated cirrhosis: } 24 \text { weeks } \\
\text { Treatment-naïve and treatment- } \\
\text { experienced with decompensated } \\
\text { cirrhosis: } 12 \text { weeks with RBV } \\
\text { Treatment-naïve and treatment- } \\
\text { experienced liver transplant recipients } \\
\text { with no cirrhosis or with compensated } \\
\text { cirrhosis: } 12 \text { weeks with RBV }\end{array}$ \\
\hline Alberta & $\begin{array}{l}\text { For treatment-naive or treatment-experienced adult patients with } \\
\text { chronic hepatitis C infection who meet all of the following criteria: } \\
\text { I) Prescribed by a hepatologist, gastroenterologist, infectious disease } \\
\text { specialist, or a designated prescriber; } \\
\text { II) Laboratory confirmed hepatitis C genotype 1; } \\
\text { III) Laboratory confirmed quantitative HCV RNA value within the } \\
\text { last } 6 \text { months } \\
\text { IV) Fibrosis stage of F0 or greater (Metavir scale or equivalent); } \\
\text { Exclusion criteria for Alberta: } \\
\text { - Patients currently being treated with another HCV antiviral agent } \\
\text { - Retreatment for failure or re-infection in patients who have received } \\
\text { an adequate prior course of an HCV direct-acting antiviral drug } \\
\text { regimen may be considered on an exceptional case-by-case basis. }\end{array}$ & $\begin{array}{l}\text { - Treatment-naive, without cirrhosis, } \\
\text { recent quantitative hepatitis C viral } \\
\text { load less than } 6 \\
\text { M IU/mL: } 8 \text { weeks or } 12 \text { weeks ( } 3 \text { ) } \\
\text { - Treatment-naive, without cirrhosis, } \\
\text { viral load } \geq 6 \mathrm{M} \text { IU/mL: } 12 \\
\text { weeks } \\
\text { - Treatment-naive, with compensated } \\
\text { cirrhosis (4): } 12 \text { weeks } \\
\text { - Treatment-experienced, without } \\
\text { cirrhosis: } 12 \text { weeks } \\
\text { - Treatment-naive or treatment- } \\
\text { experienced with decompensated } \\
\text { cirrhosis (5): } 12 \text { weeks } \\
\text { in combination with ribavirin } \\
\text { - Treatment-naive or treatment- } \\
\text { experienced liver transplant recipients, } \\
\text { without cirrhosis } \\
\text { or with compensated cirrhosis (4): } 12 \\
\text { weeks in combination with ribavirin }\end{array}$ \\
\hline Saskatchewan & $\begin{array}{l}\text { For treatment-naive or treatment-experienced adult patients with } \\
\text { chronic hepatitis C infection who meet all of the following criteria: } \\
\text { I) Prescribed by a hepatologist, gastroenterologist, infectious disease } \\
\text { specialist, or a designated prescriber; } \\
\text { II) Laboratory confirmed hepatitis C genotype } 1 \text {; } \\
\text { III) Laboratory confirmed quantitative HCV RNA value within the } \\
\text { last } 6 \text { months }\end{array}$ & $\begin{array}{l}\text { Treatment-naïve, non-cirrhotic, viral } \\
\text { load }<6 \mathrm{M} \text { IU/mL: } 8 \text { weeks or } 12 \\
\text { weeks }(* \text { For this population cohort, } \\
\text { evidence has shown that the SVR rates } \\
\text { for the } 8 \text {-week and } 12 \text {-week treatment } \\
\text { regimens are similar. Treatment } \\
\text { regimens of up to } 12 \text { weeks are } \\
\text { recognized as a Health Canada } \\
\text { approved treatment option. Patients }\end{array}$ \\
\hline
\end{tabular}




\begin{tabular}{|c|c|c|}
\hline & & $\begin{array}{l}\text { may be considered for } 12 \text { weeks of } \\
\text { coverage if they have borderline or } \\
\text { severe fibrosis or if they are co- } \\
\text { infected with HIV.) } \\
\text { Treatment-naïve, non-cirrhotic, viral } \\
\text { load } \geq 6 \mathrm{M} \text { IU/mL OR treatment-naïve, } \\
\text { cirrhotic OR treatment-experienced, } \\
\text { non-cirrhotic: } 12 \text { weeks } \\
\text { Treatment-naïve or treatment- } \\
\text { experienced with decompensated } \\
\text { cirrhosis: } 12 \text { weeks in combination } \\
\text { with ribavirin } \\
\text { Treatment-naïve or treatment- } \\
\text { experienced liver transplant recipients } \\
\text { without cirrhosis, or with compensated } \\
\text { cirrhosis: } 12 \text { weeks in combination } \\
\text { with ribavirin } \\
\text { Treatment-experienced, cirrhotic: } 24 \\
\text { weeks }\end{array}$ \\
\hline Manitoba & $\begin{array}{l}\text { For treatment-naïve/experienced (1) adult patients with chronic } \\
\text { hepatitis } \mathrm{C}(\mathrm{CHC}) \text { infection who meet ALL the following criteria: } \\
\text { i) Treatment is prescribed by a hepatologist, gastroenterologist, } \\
\text { or infectious disease specialist } \\
\text { ii) Laboratory confirmed hepatitis C genotype } 1 \\
\text { iii) Patient has a quantitative HCV RNA value within the last } 6 \\
\text { months } \\
\text { iv) Fibrosis (2) stage of F0 or greater (Metavir scale or } \\
\text { equivalent) including decompensated cirrhosis (As of April 2018) }\end{array}$ & $\begin{array}{l}\text { Genotype } 1 \text { Patient population duration } \\
\text { of therapy reimbursed: } \\
\text {-Treatment-naïve, non-cirrhotic, viral } \\
\text { load }<6 \mathrm{M} \mathrm{IU} / \mathrm{mL}=8 \text { weeks } \\
\text {-Treatment-naïve, non-cirrhotic, viral } \\
\text { load }>6 \mathrm{M} \text { IU/mL or Treatment-naïve, } \\
\text { cirrhotic, or Treatment-experienced, } \\
\text { non-cirrhotic }=12 \text { weeks } \\
\text {-Treatment-naïve or treatment- } \\
\text { experienced with decompensated } \\
\text { cirrhosis }(5)=12 \text { weeks in } \\
\text { combination with ribavirin } \\
\text {-Treatment-naïve or treatment- } \\
\text { experienced liver transplant recipients } \\
\text { without cirrhosis or with compensated } \\
\text { cirrhosis }(5)=12 \text { weeks in combination } \\
\text { with ribavirin } \\
\text {-Treatment-experienced, cirrhotic }=24 \\
\text { weeks } \\
* \text { Retreatment for failure or re-infection } \\
\text { in patients who have received an } \\
\text { adequate prior course of direct-acting } \\
\text { antiviral will be considered on a case- } \\
\text { by-case basis. }\end{array}$ \\
\hline Ontario & $\begin{array}{l}\text { For treatment-naive or treatment-experienced adult patients with } \\
\text { chronic hepatitis C infection who meet all of the following criteria: } \\
\text { I) Prescribed by a hepatologist, gastroenterologist, infectious disease } \\
\text { specialist, or a designated prescriber; } \\
\text { II) Laboratory confirmed hepatitis C genotype 1; } \\
\text { III) Laboratory confirmed quantitative HCV RNA value within the } \\
\text { last } 6 \text { months }\end{array}$ & $\begin{array}{l}\text { Treatment-naïve, non-cirrhotic, recent } \\
\text { quantitative hepatitis C viral load less } \\
\text { than } 6 \mathrm{M} \mathrm{IU/mL:} 8 \text { weeks } \\
\text { Treatment-naïve, without cirrhosis, } \\
\text { viral load greater than or equal to } 6 \mathrm{M} \\
\text { IU/mL; or treatment-naïve with } \\
\text { cirrhosis; or treatment-experienced } \\
\text { without cirrhosis: } 12 \text { weeks } \\
\text { Treatment-naïve or treatment- } \\
\text { experienced with decompensated }\end{array}$ \\
\hline
\end{tabular}




\begin{tabular}{|c|c|c|}
\hline & & $\begin{array}{l}\text { cirrhosis: } 12 \text { weeks in combination } \\
\text { with ribavirin (Ibavyr) } \\
\text { Treatment-naïve or treatment- } \\
\text { experienced liver transplant recipients } \\
\text { without cirrhosis or with compensated } \\
\text { cirrhosis: } 12 \text { weeks in combination } \\
\text { with ribavirin (Ibavyr) } \\
\text { Treatment-experienced, cirrhotic: } 24 \\
\text { weeks } \\
\text { * Retreatment is not funded. } \\
\text { Retreatment for failure or re-infection } \\
\text { in patients who have received an } \\
\text { adequate prior course of direct-acting } \\
\text { antiviral will be considered on a case- } \\
\text { by case basis through the Exceptional } \\
\text { Access Program. }\end{array}$ \\
\hline Quebec & $\begin{array}{l}\text { As monotherapy, for treatment of persons suffering from chronic } \\
\text { hepatitis C genotype } 1 \text { without decompensated cirrhosis, who have } \\
\text { never received an anti-SCV treatment. ( } 8-12 \text { weeks) } \\
\text { As monotherapy, for treatment of persons suffering from chronic } \\
\text { hepatitis C genotype } 1 \text { without cirrhosis who have experienced } \\
\text { therapeutic failure with an association of ribavirin/pegylated } \\
\text { interferon alfa administered alone or combined with a protease } \\
\text { inhibitor. (12 weeks) } \\
\text { In association with ribavirin, for treatment of chronic hepatitis C } \\
\text { genotype } 1 \text { in persons: } \\
\text {-With compensated cirrhosis and who have experienced therapeutic } \\
\text { failure with an association of ribavirin/pegylated interferon alfa } \\
\text { administered alone or combined with a protease inhibitor } \\
\text { OR } \\
\text {-With decompensated cirrhosis } \\
\text { OR } \\
\text {-Who are waiting for an organ transplant or who have received a } \\
\text { transplant } \\
\text { (12 weeks) } \\
\text { As monotherapy, for treatment of chronic hepatitis C genotype } 1 \text { in } \\
\text { persons: } \\
\text {-With compensated cirrhosis and a contraindication or a serious } \\
\text { intolerance to ribavirin and who have experienced therapeutic failure } \\
\text { with an association of ribavirin/pegylated interferon alfa } \\
\text { administered alone or combined with a protease inhibitor } \\
\text { OR } \\
\text {-With decompensated cirrhosis and a contraindication or a serious } \\
\text { intolerance to ribavirin } \\
\text { OR } \\
\text {-Who are waiting for an organ transplant or who have received a } \\
\text { transplant and who have a contraindication or a serious intolerance to } \\
\text { ribavirin. } \\
\text { (24 weeks) }\end{array}$ & 8 -24 weeks \\
\hline Nova Scotia & $\begin{array}{l}\text { For treatment-naïve or treatment-experienced* adult patients with } \\
\text { chronic hepatitis C infection at any fibrosis stage (F0-F4) who meet } \\
\text { ALL of the following criteria: } \\
\text { i) Treatment is prescribed by a hepatologist, infectious } \\
\text { disease specialist or gastroenterologist } \\
\text { ii) Laboratory confirmed hepatitis C genotype } 1 \\
\text { iii) Laboratory confirmed quantitative HCV RNA level taken }\end{array}$ & $\begin{array}{l}\text { Genotype } 1 \\
\text {-Treatment-naïve without cirrhosis, } \\
\text { who have pre-treatment HCV RNA } \\
\text { level }<6 \text { million IU/mL and mono- } \\
\text { HCV infected only: } 8 \text { weeks } \\
\text {-Treatment-naïve without cirrhosis, } \\
\text { who have pre-treatment HCV RNA }\end{array}$ \\
\hline
\end{tabular}




\begin{tabular}{|c|c|c|}
\hline & $\begin{array}{l}\text { in the last } 6 \text { months } \\
\text { iv) } \quad \text { Fibrosis stage must be provided }\end{array}$ & $\begin{array}{l}\text { level } \geq 6 \text { million IU/mL OR treatment- } \\
\text { naïve with compensated cirrhosis OR } \\
\text { treatment-naïve with advanced liver } \\
\text { fibrosis (F3 or F4) OR treatment- } \\
\text { experienced without cirrhosis OR } \\
\text { HCV/HIV co-infected without } \\
\text { cirrhosis or with compensated } \\
\text { cirrhosis: } 12 \text { weeks } \\
\text {-Treatment-experienced with } \\
\text { compensated cirrhosis: } 24 \text { weeks } \\
\text {-Decompensated cirrhosis OR liver } \\
\text { transplant recipients without cirrhosis } \\
\text { or with compensated cirrhosis: } 12 \\
\text { weeks in combination with ribavirin }\end{array}$ \\
\hline New Brunswick & $\begin{array}{l}\text { For treatment-naive or treatment-experienced adult patients with } \\
\text { chronic hepatitis C infection who meet all of the following criteria: } \\
\text { I) Laboratory confirmed hepatitis C genotype } 1 \text {; } \\
\text { II) Laboratory confirmed quantitative HCV RNA value within the } \\
\text { last } 6 \text { months } \\
\text { III) Fibrosis stage }\end{array}$ & $\begin{array}{l}\text { Treatment-naïve without cirrhosis, who } \\
\text { have pre-treatment HCV RNA level }< \\
6 \text { million IU/mL and mono-HCV } \\
\text { infected only: } 8 \text { weeks } \\
\text { Treatment-naïve without cirrhosis, who } \\
\text { have pre-treatment HCV RNA level } \geq \\
6 \text { million IU/mL OR treatment-naïve } \\
\text { with compensated cirrhosis OR } \\
\text { treatment-naïve with advanced liver } \\
\text { fibrosis (F3 or F4) OR treatment- } \\
\text { experienced without cirrhosis OR } \\
\text { HCV/HIV co-infected without } \\
\text { cirrhosis or with compensated } \\
\text { cirrhosis: } 12 \text { weeks } \\
\text { Treatment-experienced with } \\
\text { compensated cirrhosis: } 24 \text { weeks } \\
\text { Decompensated cirrhosis OR liver } \\
\text { transplant recipients without cirrhosis } \\
\text { or with compensated cirrhosis: } 12 \\
\text { weeks in combination with ribavirin }\end{array}$ \\
\hline Yukon & $\begin{array}{l}\text { For treatment-naïve or treatment-experienced*adult patients with } \\
\text { chronic hepatitis C infection at any fibrosis stage (F0-F4) who meet } \\
\text { ALL of the following criteria: } \\
\text { i) } \\
\text { Treatment is prescribed by a hepatologist, infectious } \\
\text { disease specialist or gastroenterologist } \\
\text { Laboratory confirmed hepatitis C genotype } 1,2,3,4 \text {, } \\
\text { ii) } 6 \text {, or mixed genotype } \\
\text { Laboratory confirmed quantitative HCV RNA level } \\
\text { taken in the last } 12 \text { months } \\
\text { iii) }\end{array}$ & N/A \\
\hline NWT \& Nunavut & $\begin{array}{l}\text { For adult patients with chronic hepatitis } \mathrm{C} \text { infection at any fibrosis } \\
\text { stage (F0-F4) who meet ALL of the following criteria: }\end{array}$ & $\mathrm{N} / \mathrm{A}$ \\
\hline
\end{tabular}




\begin{tabular}{|l|l|l|}
\hline & $\begin{array}{l}\text { I) Prescribed by a hepatologist, gastroenterologist, infectious disease } \\
\text { specialist, or other prescriber experienced in treating hepatitis C } \\
\text { II) Laboratory confirmed hepatitis C infection with genotype 1,2,3, } \\
4,5,6 \text {, or mixed genotype; } \\
\text { III) Laboratory confirmed quantitative HCV RNA value within the } \\
\text { last 12 months } \\
\text { *Retreatment or re-infection in patients who have received an } \\
\text { adequate prior course of direct-acting antivirals will be considered on } \\
\text { a case-by-case basis. }\end{array}$ & \\
\hline $\begin{array}{l}\text { PEI, } \\
\text { Newfoundland \& } \\
\text { Labrador }\end{array}$ & \begin{tabular}{l} 
N/A \\
\hline
\end{tabular} & N/A \\
\hline
\end{tabular}

Table 9: Sovaldi Coverage Criteria as of August 20, 2018

\begin{tabular}{|c|c|c|}
\hline Province & Coverage Criteria & Approved Duration \\
\hline British Columbia & $\begin{array}{l}\text { For the treatment of treatment-naïve or treatment-experienced adult } \\
\text { patients with CHC genotype } 2 \text { or } 3 \text { infection who meet ALL of the } \\
\text { following criteria: } \\
\text { a) Fibrosis stage of F0 or greater (Metavir scale or } \\
\text { equivalent). Special Authority requests for patients must } \\
\text { include a fibrosis score test performed in the last } 12 \\
\text { months. Acceptable methods include liver biopsy, transient } \\
\text { elastography (FibroScan) and serum biomarker panels } \\
\text { (AST-to-Platelet Ratio Index (APRI)) either alone or in } \\
\text { combination. Supporting documentation must be } \\
\text { submitted. } \\
\text { b) Treatment is prescribed by a hepatologist, a } \\
\text { gastroenterologist, an infectious disease specialist, or other } \\
\text { physicians experienced with treating hepatitis C } \\
\text { c) Laboratory confirmed hepatitis C genotype } 2 \text { or } 3 \\
\text { d) Laboratory confirmed quantitative HCV RNA test must be } \\
\text { done within the previous } 12 \text { months } \\
\text { e) Patient is NOT currently being treated with another } \\
\text { hepatitis C direct-acting antiviral drug (with the exception } \\
\text { of daclatasvir for genotype 3). }\end{array}$ & $\begin{array}{l}\frac{\text { Genotype } 2}{\text { Treatment-naïve and treatment- }} \\
\text { experienced with no cirrhosis or with } \\
\text { compensated cirrhosis: } 12 \text { weeks with } \\
\text { RBV } \\
\frac{\text { Genotype } 3}{\text { Treatment-naïve and treatment- }} \\
\text { experienced with no cirrhosis or with } \\
\text { compensated cirrhosis: } 24 \text { weeks with } \\
\text { RBV }\end{array}$ \\
\hline Alberta & $\begin{array}{l}\text { For use as combination therapy with ribavirin or daclatasvir for } \\
\text { treatment-naive or treatment-experienced adult patients with chronic } \\
\text { hepatitis C infection who meet all of the following criteria: } \\
\text { I) Prescribed by a hepatologist, gastroenterologist, infectious disease } \\
\text { specialist, or a designated prescriber; } \\
\text { II) Laboratory confirmed hepatitis C genotype } 2 \text { or genotype } 3 \text {; } \\
\text { III) Laboratory confirmed quantitative HCV RNA value within the } \\
\text { last } 6-12 \text { months; } \\
\text { IV) Fibrosis stage of F0 or greater (Metavir scale or equivalent); } \\
\text { Exclusion criteria for Alberta: } \\
\text { - Patients currently being treated with another HCV antiviral agent } \\
\text { - Retreatment for failure or re-infection in patients who have received } \\
\text { an adequate prior course of an HCV direct-acting antiviral drug } \\
\text { regimen may be considered on an exceptional case-by-case basis } \\
\text { - Combination therapy with elbasvir/grazoprevir will not be } \\
\text { considered }\end{array}$ & $\begin{array}{l}\text {-Treatment-naive or treatment } \\
\text { experienced genotype } 2 \text {, without } \\
\text { cirrhosis or with compensated } \\
\text { cirrhosis: } 12 \text { weeks with RBV } \\
\text {-Treatment-naive or treatment- } \\
\text { experienced genotype } 3 \text {, without } \\
\text { cirrhosis: } 12 \text { weeks with daclatasvir } \\
\text { - Treatment-naive or treatment- } \\
\text { experienced genotype } 3 \text {, without } \\
\text { cirrhosis or with compensated } \\
\text { cirrhosis: } 24 \text { weeks with RBV }\end{array}$ \\
\hline Saskatchewan & $\begin{array}{l}\text { For use as combination therapy with ribavirin or daclatasvir for } \\
\text { treatment-naive or treatment-experienced adult patients with chronic } \\
\text { hepatitis C infection who meet all of the following criteria: } \\
\text { I) Prescribed by a hepatologist, gastroenterologist, infectious disease } \\
\text { specialist, or a designated prescriber; } \\
\text { II) Laboratory confirmed hepatitis C genotype } 2 \text { or genotype } 3 \text {; }\end{array}$ & $\begin{array}{l}\frac{\text { Genotype } 2}{\text {-Treatment-naive or treatment }} \\
\text { experienced: } 12 \text { weeks in combination } \\
\text { with ribavirin } \\
\text { Genotype } 3\end{array}$ \\
\hline
\end{tabular}




\begin{tabular}{|c|c|c|}
\hline & $\begin{array}{l}\text { III) Laboratory confirmed quantitative HCV RNA value within the } \\
\text { last } 6 \text { months } \\
\text { (For patients who meet the eligibility criteria for sofosbuvir } \\
\text { (Sovaldi), clinicians are encouraged to choose sofosbuvir/velpatasvir } \\
\text { (Epclusa) or sofosbuvir in combination with daclatasvir (Daklinza) as } \\
\text { one of the preferred therapeutic options over sofosbuvir with } \\
\text { ribavirin regimens for treatment of genotype } 2 \text { or } 3 \text { patients only. } \\
\text { This recommendation is based on evidence that Epclusa or Daklinza } \\
\text { in combination with sofosbuvir offers advantages in some patient } \\
\text { populations, including potentially higher SVR rates and a shorter } \\
\text { course of therapy for genotype } 3 \text { infections.) }\end{array}$ & $\begin{array}{l}\text {-Treatment-naïve or treatment- } \\
\text { experienced without cirrhosis: } 12 \\
\text { weeks in combination with daclatasvir } \\
\text { OR } 24 \text { weeks in combination with } \\
\text { ribavirin } \\
\text {-Treatment-naïve or treatment- } \\
\text { experienced with compensated or } \\
\text { decompensated cirrhosis: } 12 \text { weeks in } \\
\text { combination with daclatasvir and } \\
\text { ribavirin OR } 24 \text { weeks in combination } \\
\text { with ribavirin } \\
\text {-Treatment-naïve or treatment- } \\
\text { experienced post liver transplant: } 12 \\
\text { weeks in combination with daclatasvir } \\
\text { and ribavirin } \\
\text { *Combination therapy with } \\
\text { elbasvir/grazoprevir (Zepatier) will not } \\
\text { be considered for funding. }\end{array}$ \\
\hline Manitoba & $\begin{array}{l}\text { In combination with ribavirin or daclatasvir or both for treatment } \\
\text { naïve/experienced (1) adult patients with chronic hep C (CHC) } \\
\text { infection who meet ALL the following criteria: } \\
\text { i) Treatment is prescribed by a hepatologist, gastroenterologist, } \\
\text { or infectious disease specialist } \\
\text { ii) Lab confirmed hep C genotype } 2 \text { or } 3 \\
\text { iii) Patient has a quantitative HCV RNA value within the last } 6 \\
\text { months } \\
\text { iv) Fibrosis (2) stage of F2 or greater (Metavir scale or } \\
\text { equivalent) As of April } 2018 \text {. } \\
\text { *For patients who meet the eligibility criteria for sofosbuvir } \\
\text { (Sovaldi), clinicians are encouraged to choose sofosbuvir/velpatasvir } \\
\text { (Epclusa) or sofosbuvir in combination with daclatasvir (Daklinza) as } \\
\text { one of the preferred therapeutic options over sofosbuvir with } \\
\text { ribavirin regimens for treatment of gen } 2 \text { or } 3 \text { patients only. } \\
\text { *This recommendation is based on evidence that Epclusa or Daklinza } \\
\text { in combo with sofosbuvir offers advantages in some patient } \\
\text { populations, including potentially higher SVR rates and a shorter } \\
\text { course of therapy for gen } 3 \text { infections. }\end{array}$ & $\begin{array}{l}\text { Genotype } 2 \\
\text {-Treatment-naïve/experienced without } \\
\text { cirrhosis; or compensated cirrhosis (5) } \\
=12 \text { weeks in combination with } \\
\text { ribavirin } \\
\text { Genotype } 3 \\
\text {-Treatment naïve/experienced without } \\
\text { cirrhosis = } 12 \text { weeks in combination } \\
\text { with daclatasvir } \\
\text {-Treatment naïve/experienced with } \\
\text { compensated cirrhosis (5); or post liver } \\
\text { transplant = } 12 \text { weeks in combination } \\
\text { with daclatasvir and ribavirin }\end{array}$ \\
\hline Ontario & $\begin{array}{l}\text { For use as combination therapy with ribavirin or daclatasvir for } \\
\text { treatment-naive or treatment-experienced adult patients with chronic } \\
\text { hepatitis C infection who meet all of the following criteria: } \\
\text { I) Prescribed by a hepatologist, gastroenterologist, infectious disease } \\
\text { specialist, or a designated prescriber; } \\
\text { II) Laboratory confirmed hepatitis C genotype } 2 \text { or } 3 \\
\text { III) Laboratory confirmed quantitative HCV RNA value within the } \\
\text { last } 6 \text { months } \\
\text { For patients who meet the eligibility criteria for sofosbuvir (Sovaldi), } \\
\text { clinicians are encouraged to choose sofosbuvir/velpatasvir (Epclusa) } \\
\text { or sofosbuvir in combination with daclatasvir (Daklinza) as one of } \\
\text { the preferred therapeutic options over sofosbuvir with ribavirin } \\
\text { regimens for treatment of genotype } 2 \text { or } 3 \text { patients only. This } \\
\text { recommendation is based on evidence that Epclusa or Daklinza in } \\
\text { combination with sofosbuvir offers advantages in some patient } \\
\text { populations, including potentially higher SVR rates and a shorter } \\
\text { course of therapy for genotype } 3 \text { infections. }\end{array}$ & $\begin{array}{l}\text { Genotype } 2 \\
\text {-Treatment-naïve or treatment- } \\
\text { experienced: } 12 \text { weeks in combination } \\
\text { with ribavirin (Ibavyr) } \\
\text { Genotype } 3 \\
\text {-Treatment-naïve or treatment- } \\
\text { experienced without cirrhosis: } 12 \\
\text { weeks in combination with daclatasvir } \\
\text {-Treatment-naïve or treatment- } \\
\text { experienced with compensated } \\
\text { cirrhosis or decompensated cirrhosis or } \\
\text { post-liver transplant: } 12 \text { weeks in } \\
\text { combination with daclatasvir and } \\
\text { ribavirin } \\
\text {-Treatment-naïve or treatment- } \\
\text { experienced without cirrhosis, or with } \\
\text { compensated cirrhosis or with } \\
\text { decompensated cirrhosis or post-liver } \\
\text { transplant: } 24 \text { weeks in combination } \\
\text { with ribavirin }\end{array}$ \\
\hline Quebec & $\begin{array}{l}\text { In association with ribavirin and pegylated interferon alfa, for } \\
\text { treatment of persons suffering from chronic hepatitis } \mathrm{C} \text { genotype } 1 \text { or }\end{array}$ & Authorization granted for $12-24$ weeks \\
\hline
\end{tabular}




\begin{tabular}{|c|c|c|}
\hline & $\begin{array}{l}\text { 4, who are not HIV-1 infected and who have never received an anti- } \\
\text { HCV treatment ( } 12 \text { weeks). } \\
\text { In association with ribavirin, for treatment of persons suffering from } \\
\text { chronic hepatitis C genotype } 2 \text {, who have never received anti-HCV } \\
\text { treatment OR who have a contraindication or a serious intolerance to } \\
\text { pegylated interferon alfa OR who have experienced therapeutic } \\
\text { failure with an association of ribavirin/pegylated interferon alfa (12 } \\
\text { weeks). } \\
\text { In association with ribavirin, for treatment of persons suffering from } \\
\text { chronic hepatitis C genotype } 3 \text { who have a contraindication or a } \\
\text { serious intolerance to pegylated interferon alfa OR who have already } \\
\text { experienced therapeutic failure with an association of } \\
\text { ribavirin/pegylated interferon alfa ( } 24 \text { weeks). } \\
\text { In association with daclatasvir, for treatment of persons suffering } \\
\text { from chronic hepatitis C genotype } 3 \text { without cirrhosis who have a } \\
\text { contraindication or a serious intolerance to pegylated interferon alfa } \\
\text { or ribavirin OR who have experienced therapeutic failure with an } \\
\text { association of ribavirin/pegylated interferon alfa (12 weeks). }\end{array}$ & \\
\hline $\begin{array}{l}\text { Nova Scotia \& } \\
\text { New Brunswick }\end{array}$ & $\begin{array}{l}\text { For treatment-naïve or treatment-experienced adult patients with } \\
\text { chronic hepatitis C virus (HCV) who meet the following criteria: } \\
\text {-Lab-confirmed hepatitis C genotype } 2 \text { and } 3 \\
\text {-Quantitative HCV RNA value within the last } 6 \text { months } \\
\text {-Fibrosis stage must be provided }\end{array}$ & $\begin{array}{l}\text { Genotype } 2 \\
\text {-Without cirrhosis OR with } \\
\text { compensated cirrhosis: } 12 \text { weeks in } \\
\text { combination with ribavirin } \\
\text { Genotype } 3 \\
\text {-Without cirrhosis or with } \\
\text { compensated cirrhosis: } 24 \text { weeks in } \\
\text { combination with ribavirin } \\
\text {-Without cirrhosis: } 12 \text { weeks in } \\
\text { combination with daclatasvir } \\
\text {-With compensated or decompensated } \\
\text { cirrhosis or post-liver transplant } \\
\text { without cirrhosis or with compensated } \\
\text { cirrhosis: } 12 \text { weeks in combination } \\
\text { with daclatasvir and ribavirin }\end{array}$ \\
\hline Yukon & $\begin{array}{l}\text { For treatment-naïve or treatment-experienced*adult patients with } \\
\text { chronic hepatitis C infection at any fibrosis stage (F0-F4) who meet } \\
\text { ALL of the following criteria: } \\
\text { i) } \\
\text { Treatment is prescribed by a hepatologist, infectious } \\
\text { disease specialist or gastroenterologist } \\
\text { Laboratory confirmed hepatitis C genotype } 1,2,3,4 \text {, } \\
\text { ii) } 6 \text {, or mixed genotype } \\
\text { Laboratory confirmed quantitative HCV RNA level } \\
\text { taken in the last } 12 \text { months } \\
\text { iii) }\end{array}$ & $\mathrm{N} / \mathrm{A}$ \\
\hline NWT \& Nunavut & For adult patients with chronic hepatitis $\mathrm{C}$ infection at any fibrosis & $\mathrm{N} / \mathrm{A}$ \\
\hline
\end{tabular}




\begin{tabular}{|l|l|l|}
\hline & stage (F0-F4) who meet ALL of the following criteria: \\
& $\begin{array}{l}\text { I) Prescribed by a hepatologist, gastroenterologist, infectious disease } \\
\text { specialist, or other prescriber experienced in treating hepatitis C } \\
\text { II) **Laboratory confirmed hepatitis C infection with genotype 1, 2, } \\
3,4,5,6, \text { or mixed genotype; }\end{array}$ & \\
& $\begin{array}{l}\text { III) Laboratory confirmed quantitative HCV RNA value within the } \\
\text { last 12 months } \\
\text { *Retreatment or re-infection in patients who have received an } \\
\text { adequate prior course of direct-acting antivirals will be considered on } \\
\text { a case-by-case basis. }\end{array}$ & \\
\hline $\begin{array}{l}\text { PEI, } \\
\text { Newfoundland \& } \\
\text { Labrador }\end{array}$ & \begin{tabular}{l} 
N/A \\
\hline
\end{tabular} & \\
\hline
\end{tabular}

Table 10: Holkira Pak Coverage Criteria as of August 20, 2018

\begin{tabular}{|c|c|c|}
\hline Province & Coverage Criteria & Approved Duration \\
\hline British Columbia & $\begin{array}{l}\text { Effective March 23, 2017, BC PharmaCare will no longer approve } \\
\text { new requests for coverage. For patients whose coverage was } \\
\text { approved before March 23, 2017, PharmaCare will continue coverage } \\
\text { until their current Special Authority expires. }\end{array}$ & N/A \\
\hline Alberta & $\begin{array}{l}\text { No new patients will be approved to initiate Holkira Pak therapy after } \\
\text { March } 31,2017 \text {. }\end{array}$ & $\mathrm{N} / \mathrm{A}$ \\
\hline Saskatchewan & $\begin{array}{l}\text { This medication will only be considered for patients in whom the } \\
\text { other listed oral hepatitis C treatment alternatives are not appropriate. } \\
\text { Requests for this medication should provide details of why the listed } \\
\text { alternatives are not appropriate as well as indicating how the patient } \\
\text { meets the medical criteria below. } \\
\text { For treatment-naïve and treatment-experienced adult patients with } \\
\text { chronic hepatitis C genotype } 1 \text { infection, with compensated liver } \\
\text { disease, (including compensated cirrhosis) according to the following } \\
\text { criteria: Prescribed by a hepatologist, gastroenterologist or an } \\
\text { infectious disease specialist or other physician experienced in treating } \\
\text { hepatitis C as determined by the Drug Plan, lab-confirmed hepatitis C } \\
\text { genotype } 1 \text {, subtype 1a and } 1 \text { b required, patient has a quantitative } \\
\text { HCV RNA value within the last } 6 \text { months, fibrosis stage F2 or } \\
\text { greater (Metavir scale or equivalent). } \\
\text { *As of April } 27,2018 \text {, Saskatchewan has removed the fibrosis } \\
\text { requirement in order for DAA coverage. }\end{array}$ & $\begin{array}{l}\text { Treatment naïve and experience } \\
\text { genotype } 1 \mathrm{~b} \text {, non-cirrhotic: } 12 \text { weeks } \\
\text { Treatment naïve and experience } \\
\text { genotypes 1a, non-cirrhotic: } 12 \text { weeks } \\
\text { with RBV } \\
\text { Treatment naïve and experienced } \\
\text { genotype } 1 \mathrm{~b} \text {, cirrhotic: } 12 \text { weeks with } \\
\text { RBV } \\
\text { Treatment naïve and experienced (prior } \\
\text { relapsers and prior partial responders) } \\
\text { genotype 1a, cirrhotic: } 12 \text { weeks with } \\
\text { RBV } \\
\text { Treatment experienced genotype } 1 \mathrm{a}, \\
\text { with cirrhosis, who have had previous } \\
\text { null response to PegIFN and RBV: } 24 \\
\text { weeks with RBV }\end{array}$ \\
\hline Ontario & $\begin{array}{l}\text { The Ministry only considers funding of patients diagnosed with } \\
\text { Chronic Hepatitis C infection. Consideration on a case-by-case basis } \\
\text { through the Exceptional Access Program. Requests must include } \\
\text { clinical detail with rationale as to why all formulary funded products } \\
\text { that can be used within approved regimens cannot be considered. } \\
\text { Laboratory information provided must include the following; } \\
\text { laboratory confirmed genotype, quantitative HCV RNA values to } \\
\text { demonstrate chronic hepatitis C infection, and fibrosis stage. } \\
\text { *As of June } 28,2018\end{array}$ & $\mathrm{~N} / \mathrm{A}$ \\
\hline Quebec & $\begin{array}{l}\text { Holkira Pak remains covered by the basic prescription drug insurance } \\
\text { plan until September 6, } 2017 \text { for those insured persons who began } \\
\text { receiving this treatment before March 22, } 2017 \text {. }\end{array}$ & N/A \\
\hline Nova Scotia & $\begin{array}{l}\text { Effective May 1, 2017, Pharmacare will no longer approve new } \\
\text { requests for coverage of Holkira Pak. }\end{array}$ & N/A \\
\hline
\end{tabular}




\begin{tabular}{|c|c|c|}
\hline PEI & $\begin{array}{l}\text { Inclusion Criteria } \\
\text {-HCV genotype } 1 \text { (also indicated for genotype } 4 \text { ) } \\
\text {-18 years of age and older } \\
\text {-compensated cirrhosis } \\
\text {-stable address/phone number } \\
\text {-stable on methadone or equivalent for at least } 6 \text { months (at } \\
\text { discretion of treating physician) } \\
\text { no fibrosis restriction } \\
\text {-those with co-infections such as HCV/HIV or HCV/HBV are } \\
\text { eligible for treatment with Holkira Pak but are treated by off island } \\
\text { specialists in Hepatology or Infectious disease. } \\
\text { Exclusion criteria } \\
\text {-pregnancy (females seeking treatment cannot be pregnant at time of } \\
\text { treatment and female partners of men seeking treatment cannot be } \\
\text { pregnant) }\end{array}$ & $\mathrm{N} / \mathrm{A}$ \\
\hline Yukon & $\begin{array}{l}\text { For patients that meet the eligibility criteria below clinicians are } \\
\text { encouraged to use Holkira Pak as one of the preferred therapeutic } \\
\text { options over other covered therapies (eg: interferon-based regimens } \\
\text { with NS3/4A protease inhibitors or polymerase inhibitors). This } \\
\text { recommendation is based on Holkira Pak's advantages in some } \\
\text { patient populations, including potentially higher SVR rates, improved } \\
\text { tolerability, no need for concomitant interferon, and a shorter course } \\
\text { of therapy. } \\
\text { For treatment-naive and treatment-experienced adult patients with } \\
\text { chronic hepatitis C genotype } 1 \text { infection, with compensated liver } \\
\text { disease (including compensated cirrhosis*) according to the } \\
\text { following criteria: } \\
\text {-Treatment is prescribed by a hepatologist, infectious disease } \\
\text { specialist or gastroenterologist } \\
\text {-Lab-confirmed hepatitis C genotype } 1 \text {, subtype 1a and } 1 \text { b required } \\
\text {-Patient has quantitative HCV RNA value within the last } 6 \text { months } \\
\text {-Fibrosis stage F2 or greater (Metavir scale or equivalent) } \\
\text { Exclusion criteria: } \\
\text {-Patients currently being treated with another HCV antiviral agent } \\
\text {-Patients who have received a previous trial of Holkira Pak (re- } \\
\text { treatment requests will NOT be considered) } \\
\text {-Decompensated patients } \\
\text {-No funding for other genotypes except as noted above for genotype } \\
1 \\
\text {-Patients who have received previous NS3/4A protease inhibitor- } \\
\text { based regimens (i.e. boceprevir, telaprevir \& simeprevir based } \\
\text { regimens) } \\
\text {-Patients who have received previous sofosbuvir-based regimens } \\
* \text { This was last updated on August } 17,2018 \text { but on CATIE as of April } \\
27,2018 \text { it stated that the fibrosis requirement had been removed in } \\
\text { Yukon. }\end{array}$ & $\begin{array}{l}\text { Treatment-naïve and treatment- } \\
\text { experienced genotype } 1 \mathrm{~b} \text {, non- } \\
\text { cirrhotic: } 12 \text { weeks } \\
\text { Treatment-naïve and treatment- } \\
\text { experienced genotype } 1 \mathrm{a} \text {, non- } \\
\text { cirrhotic: } 12 \text { weeks in combination } \\
\text { with RBV } \\
\text { Treatment-naïve and treatment- } \\
\text { experienced genotype } 1 \mathrm{~b} \text {, cirrhotic: } 12 \\
\text { weeks in combination with RBV } \\
\text { Treatment-naïve and treatment- } \\
\text { experienced (prior relapsers \& prior } \\
\text { partial responders) genotype } 1 \mathrm{a}, \\
\text { cirrhotic: } 12 \text { weeks in combination } \\
\text { with RBV } \\
\text { Treatment-experienced genotype } 1 \mathrm{a} \text {, } \\
\text { with cirrhosis and who have had a } \\
\text { previous null response to PegIFN and } \\
\text { RBV: } 24 \text { weeks in combination with } \\
\text { RBV }\end{array}$ \\
\hline NWT \& Nunavut & $\begin{array}{l}\text { For the treatment of chronic hepatitis C virus (HCV) Genotype } 1 \\
\text { infection in adults with a liver fibrosis stage } \geq \text { F2 (Metavir score or } \\
\text { equivalent); AND } \\
\text { Patient is unable to take the following chronic hepatitis C } \\
\text { medications based on intolerance/contraindication: Epclusa, Harvoni, } \\
\text { Zepatier, Daklinza + Sunvepra }\end{array}$ & $\begin{array}{l}\text { Treatment naïve and experienced } \\
\text { Genotype } 1 \mathrm{~b} \text {, non-cirrhotic*: } 12 \text { weeks } \\
\text { Treatment-naïve and experienced } \\
\text { Genotype } 1 \mathrm{a} \text {, non-cirrhotic: } 12 \text { weeks } \\
\text { in combination with RBV } \\
\text { Treatment-naïve and experienced } \\
\text { Genotype } 1 \mathrm{~b} \text {, cirrhotic: } 12 \text { weeks in } \\
\text { combination with RBV }\end{array}$ \\
\hline
\end{tabular}




\begin{tabular}{|l|l|l|}
\hline & & $\begin{array}{l}\text { Treatment-naïve and experienced } \\
\text { (prior relapses and prior partial } \\
\text { responders) Genotype 1a, cirrhotic: 12 } \\
\text { weeks in combination with RBV } \\
\text { Treatment-experienced Genotype 1a, } \\
\text { with cirrhosis, and who have had a } \\
\text { previous null response to PegIFN and } \\
\text { RBV: 24 weeks in combination with } \\
\text { RBV }\end{array}$ \\
& & $\begin{array}{l}* \text { Holkira Pak with ribavirin is } \\
\text { recommended in patients with an } \\
\text { unknown Genotype 1 subtype or with } \\
\text { mixed Genotype 1 infection }\end{array}$ \\
\hline $\begin{array}{l}\text { Manitoba, New } \\
\text { Brunswick, }\end{array}$ & N/A & N/A \\
Newfoundland \& & & \\
Labrador & & \\
\hline
\end{tabular}

Table 11: Zepatier Coverage Criteria as of August 20, 2018

\begin{tabular}{|c|c|c|}
\hline Province & Coverage Criteria & Approved Duration \\
\hline British Columbia & $\begin{array}{l}\text { For the treatment of treatment-naïve or treatment-experienced adult } \\
\text { patients with CHC genotype } 1 \text { or } 4 \text { infection who meet ALL the } \\
\text { following critiera: } \\
\text { a) Fibrosis stage of F0 or greater (Metavir scale or } \\
\text { equivalent). Special Authority requests for patients must } \\
\text { include a fibrosis score test performed in the last } 12 \\
\text { months. Acceptable methods include liver biopsy, transient } \\
\text { elastography (FibroScan) and serum biomarker panels } \\
\text { (AST-to-Platelet Ratio Index (APRI)) either alone or in } \\
\text { combination. Supporting documentation must be } \\
\text { submitted. } \\
\text { Treatment is prescribed by a hepatologist, a } \\
\text { gastroenterologist, an infectious disease specialist, or other } \\
\text { physicians experienced with treating hepatitis C } \\
\text { Laboratory confirmed hepatitis C genotype } 1 \text { or } 4 \\
\text { d) Laboratory confirmed quantitative HCV RNA test must be } \\
\text { done within the previous } 12 \text { months } \\
\text { Patient is NOT currently being treated with another hepatitis C } \\
\text { direct-acting antiviral drug }\end{array}$ & $\begin{array}{l}\text { Genotype 1: } \\
\text {-Treatment-naïve with no cirrhosis or } \\
\text { with compensated cirrhosis: } 12 \text { weeks } \\
\text {-Treatment-experienced (prior } \\
\text { relapsers) with no cirrhosis or with } \\
\text { compensated cirrhosis: } 12 \text { weeks } \\
\text {-Genotype } 1 \text { b treatment-experienced } \\
\text { (on-treatment virologic failures) with } \\
\text { no cirrhosis or with compensated } \\
\text { cirrhosis: } 12 \text { weeks } \\
\text {-Genotype } 1 \text { a treatment-experienced } \\
\text { (on-treatment virologic failures) with } \\
\text { no cirrhosis or with compensated } \\
\text { cirrhosis: } 16 \text { weeks with RBV } \\
\text { Genotype } 4 \text { : } \\
\text {-Treatment-naïve with no cirrhosis or } \\
\text { with compensated cirrhosis: } 12 \text { weeks } \\
\text {-Treatment-experienced (prior } \\
\text { relapsers) with no cirrhosis or with } \\
\text { compensated cirrhosis: } 12 \text { weeks } \\
\text {-Treatment-experienced (on-treatment } \\
\text { virologic failures) patient with no } \\
\text { cirrhosis or with compensated } \\
\text { cirrhosis: } 16 \text { weeks with RBV }\end{array}$ \\
\hline $\begin{array}{l}\text { Alberta \& } \\
\text { Ontario }\end{array}$ & $\begin{array}{l}\text { For treatment-naive or treatment-experienced (1) adult patients with } \\
\text { chronic hepatitis C infection who meet all of the following criteria: } \\
\text { I) Prescribed by a hepatologist, gastroenterologist, infectious disease } \\
\text { specialist, or a designated prescriber; } \\
\text { II) Laboratory confirmed hepatitis C genotype } 1 \text { or genotype } 4 \text {; } \\
\text { III) Laboratory confirmed quantitative HCV RNA value within the } \\
\text { last } 6-12 \text { months; } \\
\text { IV) Fibrosis stage of F0 or greater }\end{array}$ & $\begin{array}{l}\text {-Treatment-naïve or treatment- } \\
\text { experienced (prior relapse), without } \\
\text { cirrhosis or with compensated } \\
\text { cirrhosis: } 12 \text { weeks } \\
\text { - Treatment-experienced genotype } 1 \mathrm{~b} \\
\text { or who have had on-treatment } \\
\text { virologic failures, without cirrhosis or } \\
\text { with compensated cirrhosis: } 12 \text { weeks } \\
\text { - Treatment-experienced genotype } 1 \mathrm{a} \\
\text { or genotype } 4 \text { who have had on- } \\
\text { treatment virologic failures, without } \\
\text { cirrhosis or with compensated }\end{array}$ \\
\hline
\end{tabular}




\begin{tabular}{|c|c|c|}
\hline & & cirrhosis: 16 weeks with RBV \\
\hline Saskatchewan & 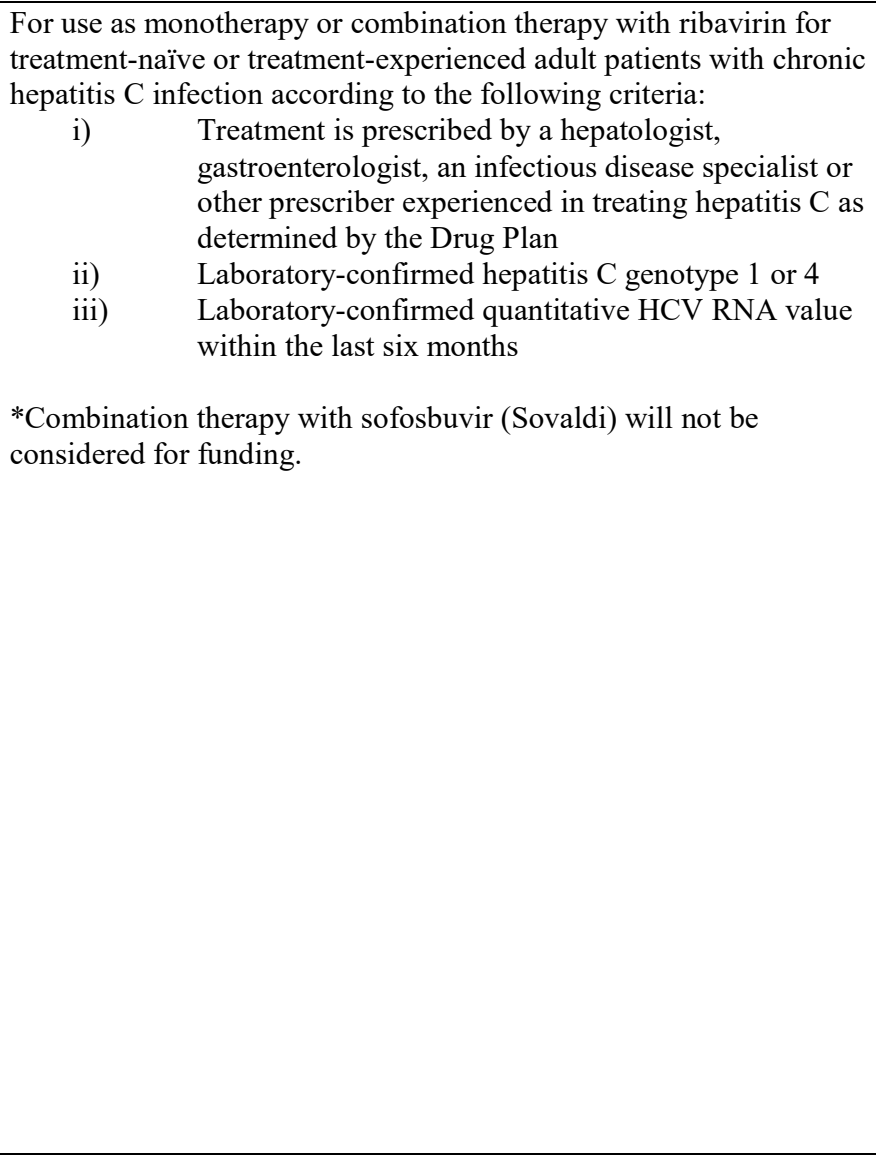 & $\begin{array}{l}\text { Genotype } 1 \\
\text {-Treatment-naïve without cirrhosis or } \\
\text { with compensated cirrhosis: } 12 \text { weeks } \\
\text { (As approved by Health Canada, } 8 \\
\text { weeks may be considered in treatment- } \\
\text { naïve genotype } 1 \mathrm{~b} \text { patients without } \\
\text { significant fibrosis or cirrhosis) } \\
\text {-Treatment-experienced relapsers } \\
\text { without cirrhosis or with compensated } \\
\text { cirrhosis: } 12 \text { weeks } \\
\text {-Treatment-experienced genotype } 1 \mathrm{~b} \\
\text { with null response, partial response, or } \\
\text { virologic breakthrough or rebound, or } \\
\text { intolerance to prior treatment: } 12 \\
\text { weeks } \\
\text {-Treatment-experienced genotype } 1 \mathrm{a} \\
\text { with null response, partial response, } \\
\text { virologic breakthrough or rebound, or } \\
\text { intolerance to prior treatment: } 16 \\
\text { weeks in combination with RBV } \\
\text { Genotype } 4 \\
\text {-Treatment-naïve without cirrhosis or } \\
\text { with compensated cirrhosis: } 12 \text { weeks } \\
\text {-Treatment-experienced relapsers } \\
\text { without cirrhosis, or with compensated } \\
\text { cirrhosis: } 12 \text { weeks } \\
\text {-Treatment-experienced with null } \\
\text { response, partial response, virologic } \\
\text { breakthrough or rebound, or } \\
\text { intolerance to prior treatment: } 16 \\
\text { weeks in combination with RBV }\end{array}$ \\
\hline Manitoba & $\begin{array}{l}\text { For treatment naïve or treatment experienced adult patients with } \\
\text { chronic Hep C genotype (gen) } 1 \text { or } 4 \text { infection who meet ALL of the } \\
\text { following: } \\
\text { i) Treatment is prescribed by a hepatologist, gastroenterologist, } \\
\text { or infectious disease specialist } \\
\text { ii) Laboratory confirmed Hep C gen } 1 \text { or gen } 4 \\
\text { iii) Patient has quantitative HCV RNA value within the last } 6 \\
\text { months } \\
\text { iv) Fibrosis (2) stage of F0 or greater (Metavir scale or } \\
\text { equivalent) (As of April } 2018 \text { ) }\end{array}$ & $\begin{array}{l}\text { Genotype } 1 \\
\text {-Treatment-naïve with/without } \\
\text { compensated cirrhosis }(5)=12 \text { weeks } \\
\text {-Treatment-experienced gen } 1 \mathrm{~b} \text { patient } \\
\text { switch on-treatment virologic failures } \\
\text { (6) and treatment-experienced gen } 1 \mathrm{a} \\
\text { and } 1 \mathrm{~b} \text { relapses with/without } \\
\text { compensated cirrhosis }(5)=12 \text { weeks } \\
\text {-Treatment-experienced gen } 1 \text { a who } \\
\text { have had on-treatment virologic } \\
\text { failures }(6)=16 \text { weeks in combo with } \\
\text { ribavirin } \\
\text { *As approved by HC, } 8 \text { weeks may be } \\
\text { considered in treatment-naïve gen } 1 \mathrm{~b} \\
\text { patients without significant fibrosis or } \\
\text { cirrhosis as determined by liver biopsy } \\
\text { (i.e. Metavir F0-F2) or by non-invasive } \\
\text { tests. } \\
\text { Genotype } 4 \\
\text {-Treatment-naïve, treatment- } \\
\text { experienced relapses, with/without } \\
\text { compensated cirrhosis (5) = 12 weeks } \\
\text {-Treatment-experienced who have had } \\
\text { on-treatment virologic failures }(6)=16 \\
\text { weeks in combo with ribavirin } \\
\text { *Retreatment for failure or re-infection }\end{array}$ \\
\hline
\end{tabular}




\begin{tabular}{|c|c|c|}
\hline & & $\begin{array}{l}\text { in patients who have received an } \\
\text { adequate prior course of direct-acting } \\
\text { antiviral will be considered on a case- } \\
\text { by-case basis. }\end{array}$ \\
\hline Quebec & $\begin{array}{l}\text { As monotherapy or in combination with ribavirin for treatment of } \\
\text { persons suffering with chronic hepatitis } C \text { genotype } 1 \text { or } 4 \text { without } \\
\text { decompensated cirrhosis. }\end{array}$ & $\begin{array}{l}\text { Authorization is granted for } 12-16 \\
\text { weeks. }\end{array}$ \\
\hline Nova Scotia & $\begin{array}{l}\text { For treatment-naïve or treatment-experienced adult patients with } \\
\text { chronic hepatitis C virus (HCV) without cirrhosis or with } \\
\text { compensated cirrhosis who meet the following criteria: } \\
\text { I) Prescribed by a hepatologist, gastroenterologist, infectious disease } \\
\text { specialist, or a designated prescriber; } \\
\text { II)Laboratory confirmed hepatitis C genotype } 1 \text { or genotype } 4 \text {; } \\
\text { III) Laboratory confirmed quantitative HCV RNA value within the } \\
\text { last } 6 \text { months } \\
\text { IV) Fibrosis stage must be provided }\end{array}$ & $\begin{array}{l}\text { Genotype } 1 \text { : } \\
\text {-Treatment-naïve and treatment- } \\
\text { experienced prior relapsers: } 12 \text { weeks } \\
\text { ( } 8 \text { weeks may be considered in } \\
\text { treatment-naïve genotype } 1 \mathrm{~b} \text { patients } \\
\text { without significant fibrosis or } \\
\text { cirrhosis) } \\
\text { Genotype } 1 \mathrm{~b} \text { : } \\
\text {-Treatment-experienced on-treatment } \\
\text { virologic failures: } 12 \text { weeks } \\
\text { Genotype 1a: } \\
\text {-Treatment-experienced on-treatment } \\
\text { virologic failures: } 16 \text { weeks in } \\
\text { combination with ribavirin } \\
\text { Genotype } 4 \text { : } \\
\text {-Treatment-naïve or treatment- } \\
\text { experienced prior relapsers: } 12 \text { weeks } \\
\text {-Treatment-experienced on-treatment } \\
\text { virologic failures: } 16 \text { weeks in } \\
\text { combination with ribavirin }\end{array}$ \\
\hline PEI & N/A & $\mathrm{N} / \mathrm{A}$ \\
\hline New Brunswick & $\begin{array}{l}\text { For treatment-naïve or treatment-experienced adult patients with } \\
\text { chronic hepatitis } \mathrm{C} \text { virus (HCV) without cirrhosis or with } \\
\text { compensated cirrhosis who meet the following criteria: } \\
\text {-Lab-confirmed hepatitis C genotype } 1 \text { or } 4 \\
\text {-Quantitative HCV RNA value within the last } 6 \text { months } \\
\text {-Fibrosis stage }\end{array}$ & $\begin{array}{l}\frac{\text { Genotype } 1}{\text {-Treatment-naïve or treatment- }} \\
\text { experienced prior relapsers: } 12 \text { weeks } \\
\text { ( } 8 \text { weeks may be considered in } \\
\text { treatment-naïve genotype } 1 \mathrm{~b} \text { patients } \\
\text { without significant fibrosis or } \\
\text { cirrhosis) } \\
\text { Genotype } 1 \mathrm{~b} \\
\text {-Treatment-experienced on-treatment } \\
\text { virologic failures: } 12 \text { weeks } \\
\text { Genotype 1a } \\
\text {-Treatment-experienced on-treatment } \\
\text { virologic failures: } 16 \text { weeks in } \\
\text { combination with ribavirin } \\
\text { Genotype } 4 \\
\text {-Treatment-naïve or treatment- } \\
\text { experienced prior relapsers: } 12 \text { weeks } \\
\text {-Treatment-experienced on-treatment } \\
\text { virologic failures: } 16 \text { weeks in } \\
\text { combination with ribavirin }\end{array}$ \\
\hline $\begin{array}{l}\text { Newfoundland \& } \\
\text { Labrador }\end{array}$ & $\begin{array}{l}\text { For treatment-naive or treatment-experienced (1) adult patients with } \\
\text { chronic hepatitis C infection who meet all of the following criteria: } \\
\text { I) Prescribed by a hepatologist, gastroenterologist, infectious disease } \\
\text { specialist, or a designated prescriber; } \\
\text { II)Laboratory confirmed hepatitis C genotype } 1 \text { or genotype } 4 \text {; } \\
\text { III) Laboratory confirmed quantitative HCV RNA value within the } \\
\text { last } 6 \text { months } \\
\text { IV) Fibrosis stage F2 or greater (Metavir scale or equivalent) or }\end{array}$ & $\begin{array}{l}\text { Genotype } 1 \\
\text {-Treatment-naïve or treatment- } \\
\text { experienced prior relapsers: } 12 \text { weeks } \\
\frac{\text { Genotype } 1 \mathrm{~b}}{\text {-Treatment-experienced on-treatment }} \\
\text { virologic failures: } 12 \text { weeks }\end{array}$ \\
\hline
\end{tabular}




\begin{tabular}{|c|c|c|}
\hline & $\begin{array}{l}\text { Fibrosis stage less than F2 (Metavir scale or equivalent) and at least } \\
\text { one of the following: } \\
\text {-Co-infected with HIV or HBV } \\
\text {-Post-organ transplant (liver and/or non-liver transplant) } \\
\text {-Extra-hepatic manifestations } \\
\text {-Chronic kidney disease stage } 3,4 \text {, or } 5 \text { as defined by the National } \\
\text { Kidney Foundation Kidney Disease Outcomes Quality Initiative } \\
\text {-Co-existent liver disease with diagnostic evidence of fatty liver } \\
\text { disease (e.g. non-alcoholic steatohepatitis) } \\
\text {-Patients with diabetes being treated with antihyperglycemic } \\
\text { medications } \\
\text {-Woman of childbearing age who is planning a pregnancy within } \\
\text { the next } 12 \text { months }\end{array}$ & $\begin{array}{l}\text { Genotype 1a } \\
\text {-Treatment-experienced on-treatment } \\
\text { virologic failures: } 16 \text { weeks in } \\
\text { combination with ribavirin } \\
\text { Genotype } 4 \\
\text {-Treatment-naïve or treatment- } \\
\text { experienced prior relapsers: } 12 \text { weeks } \\
\text {-Treatment-experienced on-treatment } \\
\text { virologic failures: } 16 \text { weeks in } \\
\text { combination with ribavirin }\end{array}$ \\
\hline Yukon & $\begin{array}{l}\text { For treatment-naïve or treatment-experienced* adult patients with } \\
\text { chronic hepatitis C infection at any fibrosis stage (F0-F4) who meet } \\
\text { ALL of the following criteria: } \\
\text { i) Treatment is prescribed by a hepatologist, infectious } \\
\text { disease specialist or gastroenterologist } \\
\text { ii) Laboratory confirmed hepatitis C genotype } 1,2,3,4,5,6 \text {, } \\
\text { or mixed genotype } \\
\text { iii) Laboratory confirmed quantitative HCV RNA level taken } \\
\text { in the last } 12 \text { months } \\
\text { Retreatment for failure or re-infection in patients who have received } \\
\text { an adequate prior course of direct-acting antivirals will be considered } \\
\text { on a case-by-case basis under the formulary exception process. } \\
\text { All exception requests should include: } \\
\text {-Lab-confirmed hepatitis C genotype } \\
\text {-Quantitative HCV RNA value within the last } 12 \text { months } \\
\text {-Fibrosis stage } \\
\text { *Treatment-experienced is defined as those who have been } \\
\text { previously treated with a PegIFN/RBV regimen (including regimens } \\
\text { containing an HCV protease inhibitor), and have not experienced an } \\
\text { adequate response. }\end{array}$ & N/A \\
\hline NWT \& Nunavut & $\begin{array}{l}\text { For adult patients with chronic hepatitis C infection at any fibrosis } \\
\text { stage (F0-F4) who meet ALL of the following criteria: } \\
\text { I) Prescribed by a hepatologist, gastroenterologist, infectious disease } \\
\text { specialist, or other prescriber experienced in treating hepatitis C } \\
\text { II) Laboratory confirmed hepatitis C infection with genotype } 1,2,3 \text {, } \\
4,5,6 \text {, or mixed genotype; } \\
\text { III) Laboratory confirmed quantitative HCV RNA value within the } \\
\text { last } 12 \text { months } \\
\text { * Retreatment for failure or re-infection in patients who have received } \\
\text { an adequate prior course of direct-acting antivirals will be considered } \\
\text { on a case-by-case basis. }\end{array}$ & $\mathrm{N} / \mathrm{A}$ \\
\hline
\end{tabular}

Table 12: Vosevi Coverage Criteria as of August 20, 2018

\begin{tabular}{|l|l|l|}
\hline \multicolumn{1}{|c|}{ Province } & \multicolumn{1}{|c|}{ Coverage Criteria } & \multicolumn{1}{|c|}{ Approved Duration } \\
\hline British Columbia & $\begin{array}{l}\text { For the treatment of direct-acting antivirals (DAA) experienced } \\
\text { including: NS5A Inhibitor treatment-experienced adult patients with }\end{array}$ & $\begin{array}{l}\text { Treatment regimens for genotype 1, 2, } \\
3,5, \text { or 6 DAA experienced adult } \\
\text { patients with NS5A Inhibitor }\end{array}$ \\
& $\begin{array}{l}\text { CHC genotype 1, 2, 3, 4, 5, or 6 infection; or Non-NS5A Inhibitor } \\
\text { sofosbuvir-containing regimen treatment-experienced adult patients } \\
\text { with CHC genotype 1, 2, 3, or 4 infection who meet ALL of the } \\
\text { following criteria: }\end{array}$ & $\begin{array}{l}\text { cirrhosis or with compensated } \\
\text { cirrhosis: } 12 \text { weeks }\end{array}$ \\
& $\begin{array}{l}\text { a) Fibrosis stage of F0 or greater (Metavir scale or } \\
\text { equivalent). Special Authority requests for patients must }\end{array}$ & \\
\hline
\end{tabular}




\begin{tabular}{|c|c|c|}
\hline & $\begin{array}{l}\text { include a fibrosis score test performed in the last } 12 \\
\text { months. Acceptable methods include liver biopsy, transient } \\
\text { elastography (FibroScan) and serum biomarker panels } \\
\text { (AST-to-Platelet Ratio Index (APRI)) either alone or in } \\
\text { combination. Supporting documentation must be } \\
\text { submitted. } \\
\text { b) Treatment is prescribed by a hepatologist, a } \\
\text { gastroenterologist, an infectious disease specialist, or other } \\
\text { physicians experienced with treating hepatitis C } \\
\text { c) Laboratory confirmed hepatitis C genotype 1, 2, 3, 4, 5, or } \\
6 \text { Laboratory confirmed quantitative HCV RNA test must be } \\
\text { d) done within the previous } 12 \text { months at SVR12 or SVR24 } \\
\text { e) Patient is NOT currently being treated with another } \\
\text { hepatitis C direct-acting antiviral drug }\end{array}$ & $\begin{array}{l}\text { Treatment regimens for genotype } 1,2 \text {, } \\
3 \text {, or } 4 \text { DAA experienced adults with } \\
\text { non-NS5A inhibitor, sofosbuvir- } \\
\text { containing regiment treatment- } \\
\text { experienced with no cirrhosis or with } \\
\text { compensated cirrhosis: } 12 \text { weeks }\end{array}$ \\
\hline Alberta & $\begin{array}{l}\text { Is not on EDS Criteria List (published April 1, 2018). It only became } \\
\text { available through Alberta Pharmacare on May } 1,2018 \text {. }\end{array}$ & N/A \\
\hline Saskatchewan & $\begin{array}{l}\text { For use as monotherapy for treatment-experienced adult patients with } \\
\text { chronic hepatitis C infection according to the following criteria: } \\
\text { i) } \\
\text { Treatment is prescribed by a hepatologist, } \\
\text { gastroenterologist, an infectious disease specialist or } \\
\text { other prescriber experienced in treatment hepatitis C } \\
\text { ii) Laboratory-confirmed hepatitis C genotype } 1,2,3,4 \text {, } \\
\text { 5, 6, or mixed genotypes } \\
\text { iii) Laboratory-confirmed quantitative HCV RNA value } \\
\text { within the last } 6 \text { months }\end{array}$ & $\begin{array}{l}\text { Treatment-experienced, non-cirrhotic } \\
\text { or compensated cirrhosis: } 12 \text { weeks }\end{array}$ \\
\hline Manitoba & $\begin{array}{l}\text { For treatment-experienced adult patients with chronic hepatitis C } \\
\text { genotype } 1,2,3,4,5,6 \text {, or mixed genotypes infection. } \\
\text { Complete criteria may be obtained from the EDS office at Manitoba } \\
\text { Health. } \\
\text { Request for coverage must be made by a hepatologist, } \\
\text { gastroenterologist or an infectious disease specialist. } \\
\text { *Bulletin } 99, \text { July } 19,2018\end{array}$ & N/A \\
\hline Ontario & 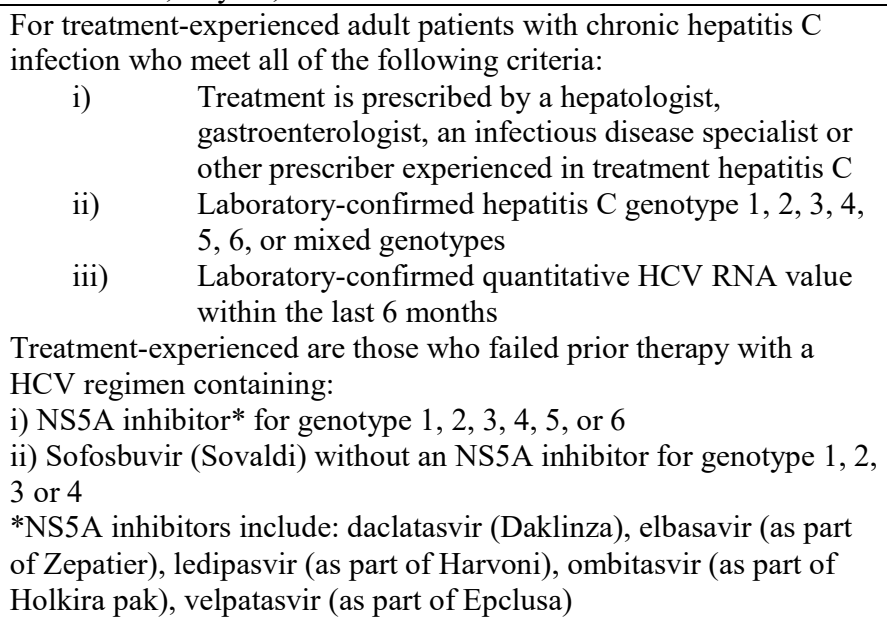 & $\begin{array}{l}\text { Treatment-experienced, non-cirrhotic } \\
\text { or compensated cirrhosis: } 12 \text { weeks }\end{array}$ \\
\hline Quebec & $\begin{array}{l}\text { As monotherapy, for treatment of persons suffering from chronic } \\
\text { hepatitis C, without decompensated cirrhosis, infected by: } \\
\text {-Genotype } 1,2,3,4,5 \text {, or } 6 \text { and having experienced a therapeutic } \\
\text { failure with a treatment containing a NS5A inhibitor } \\
\text { OR } \\
\text {-Genotype } 1,2,3 \text {, or } 4 \text { and having experienced a therapeutic failure } \\
\text { with a sofosbuvir-based treatment, but without a NS5A inhibitor }\end{array}$ & 12 weeks \\
\hline New Brunswick & $\begin{array}{l}\text { For treatment-experienced adult patients with chronic hepatitis } \mathrm{C} \\
\text { virus }(\mathrm{HCV}) \text { who meet the following criteria: }\end{array}$ & $\begin{array}{l}\text { Patients with compensated cirrhosis or } \\
\text { without cirrhosis: } 12 \text { weeks }\end{array}$ \\
\hline
\end{tabular}




\begin{tabular}{|c|c|c|}
\hline & $\begin{array}{l}\text {-Must be prescribed by a hepatologist, gastroenterologist, or } \\
\text { infectious disease specialist (or other physician experienced in } \\
\text { treating a patient with hepatitis C infection) } \\
\text {-Lab-confirmed hepatitis C genotype } 1,2,3,4,5,6 \text {, or mixed } \\
\text { genotype } \\
\text {-Quantitative HCV RNA value within the last } 6 \text { months } \\
\text { Treatment-experienced is defined as a patient who has been } \\
\text { previously treated with an NS5A inhibitor for genotype } 1,2,3,4,5 \text {, } \\
\text { or } 6 \text { or sofosbuvir without an NS5A inhibitor for genotype } 1,2,3 \text {, or } \\
4 \text { and who has not experienced an adequate response. }\end{array}$ & \\
\hline $\begin{array}{l}\text { Yukon, PEI, } \\
\text { Nova Scotia, } \\
\text { Newfoundland \& } \\
\text { Labrador }\end{array}$ & ( & $\mathrm{N} / \mathrm{A}$ \\
\hline NWT \& Nunavut & $\begin{array}{l}\text { For treatment-experienced adult patients with: } \\
\text {-Chronic hepatitis C at any fibrosis stage (F0-F4) and } \\
\text {-Detectable levels of HCV RNA in the last } 12 \text { months } \\
\text { AND } \\
\text { Treatment-experienced having failed a prior therapy with an HCV } \\
\text { regimen containing: } \\
\text {-NS5A inhibitor: daclatasvir (Daklinza), elbasvir (part of Zepatier), } \\
\text { ledipasvir (part of Harvoni), ombitasvir (part of Holkira Pak), } \\
\text { velpatasvir (part of Epclusa) for genotype } 1,2,3,4,5 \text {, or } 6 \text {; OR } \\
\text {-Sofosbuvir (Sovaldi) without an NS5A inhibitor for genotype 1, 2, } 3 \\
\text { or } 4\end{array}$ & $\mathrm{~N} / \mathrm{A}$ \\
\hline
\end{tabular}

1. BC PharmaCare Formulary Search. Last updated August 7, 2018. Retrieved from

https://pharmacareformularysearch.gov.bc.ca/fac es/Search.xhtml

2. BC List of Limited Coverage and Non-Reference Drugs Requiring Special Authority Approval.

Retrieved from

https://www2.gov.bc.ca/gov/content/health/practi tioner-professional-

resources/pharmacare/prescribers/specialauthority

3. Alberta Health. Interactive Drug Benefit List.

Drug Search. Last updated August 19, 2018.

Retrieved from

https://idbl.ab.bluecross.ca/idbl/load.do

4. Alberta Drug Benefit List. Section 3. Criteria for Special Authorization of Select Drug Products.

Effective April 1, 2018. Retrieved from https://www.ab.bluecross.ca/dbl/pdfs/dbl_sec3.p df

5. Government of Saskatchewan. Drug Plan and Extended Benefits Branch. Saskatchewan Online Formulary Database. Last updated July 30, 2018. Retrieved from

http://formulary.drugplan.ehealthsask.ca/SearchF ormulary

6. Government of Saskatchewan. Appendix A. Exception Drug Status Program. Retrieved from http://formulary.drugplan.health.gov.sk.ca/PDFs/ APPENDIXA.pdf

7. Ontario Drug Benefit Formulary/Comparative
Drug Index. Effective July 31, 2018. Retrieved from https://www.formulary.health.gov.on.ca/formular $\mathrm{y} /$

8. Ministry of Health and Long-term Care Exceptional Access Program (EAP). EAP Reimbursement Criteria for Frequently Requested Drugs. Updated August 20, 2018. Retrieved from http://www.health.gov.on.ca/en/pro/programs/dr ugs/pdf/frequently_requested_drugs.pdf

9. Quebec Rule of Health Insurance. List of Medications. Last updated on August 16, 2018. Retrieved from http://www.ramq.gouv.qc.ca/SiteCollectionDocu ments/liste med/Liste med 201808 16 en.pdf

10. Nova Scotia Drug Formulary. Last updated August 2018. Retrieved from https://novascotia.ca/dhw/pharmacare/documents /formulary.pdf

11. Nova Scotia Appendix III - Criteria for Coverage of Exception Status Drugs. August 2018. Retrieved from https:/novascotia.ca/dhw/pharmacare/documents /formulary.pdf

12. P.E.I. Pharmacare Formulary. Last updated July 2018. Retrieved from https://www.princeedwardisland.ca/sites/default/ files/publications/pei pharmacare formulary.pdf

13. New Brunswick Drug Plans Formulary. August 2018. Retrieved from 
http://www2.gnb.ca/content/dam/gnb/Departmen

ts/h-

s/pdf/en/NBDrugPlan/NewBrunswickDrugPlans Formulary.pdf

14. New Brunswick Drug Plans Special Authorization Criteria. August 2018. Retrieved from

http://www2.gnb.ca/content/dam/gnb/Departmen ts/hs/pdf/en/NBDrugPlan/SpecialAuthorization/Spec ial_Authorization_Criteria-e.pdf

15. Newfoundland \& Labrador Interchangeable Drug Products Formulary. Effective April 1, 2018 September 30, 2018. Retrieved from https://www.health.gov.nl.ca/health/nlpdp/formu laryvol78.pdf

16. Newfoundland \& Labrador. Criteria for the coverage of special authorization drugs. Updated
July 2015. Retrieved from https://www.health.gov.nl.ca/health/prescription/ special auth drug products.pdf

17. Yukon Health \& Social Services. Yukon Drug Formulary. Last updated August 17, 2018.

Retrieved from

http://apps.gov.yk.ca/drugs/f?p=161:9000:41237 21029236531

18. Government of Canada. Non-Insured Health Benefits - Drug Benefit List Spring 2018.

Published June 27, 2018. Appendix A - Limited Use Benefits and Criteria. 08:00 Anti-Infective Agents. Retrieved from https://www.canada.ca/en/indigenous-servicescanada/services/non-insured-health-benefitsfirst-nations-inuit/benefits-services-under-noninsured-health-benefits-program/drugspharmacy-benefits/drug-benefit-list/app-a.html 